\title{
Long-Term Estrogen Receptor Beta Agonist Treatment Modifies the Hippocampal Transcriptome in Middle-Aged Ovariectomized Rats
}

\author{
Miklós Sárvári ${ }^{1}$, Imre Kalló ${ }^{1,2}$, Erik Hrabovszky ${ }^{1}$, Norbert Solymosi ${ }^{3}$, Annie Rodolosse ${ }^{4}$ \\ and Zsolt Liposits ${ }^{1,2 *}$ \\ ${ }^{1}$ Laboratory of Endocrine Neurobiology, Institute of Experimental Medicine, Hungarian Academy of Sciences, Budapest, \\ Hungary, ${ }^{2}$ Faculty of Information Technology and Bionics, Pázmány Péter Catholic University, Budapest, Hungary, ${ }^{3}$ Faculty of \\ Veterinary Science, Szent István University, Budapest, Hungary, ${ }^{4}$ Functional Genomics Core, Institute for Research in \\ Biomedicine, Barcelona, Spain
}

OPEN ACCESS

Edited by:

Alessandro Tozzi,

University of Perugia, Italy

Reviewed by:

Christian J. Pike,

University of Southern California, USA

Nuno Sousa,

University of Minho, Portugal

Richard G. Hunter,

Rockefeller University, USA

*Correspondence:

Zsolt Liposits

liposits@koki.hu

Received: 21 March 2016 Accepted: 27 May 2016

Published: 10 June 2016

Citation:

Sárvári M, Kalló I, Hrabovszky E,

Solymosi N, Rodolosse A and

Liposits Z (2016) Long-Term Estrogen

Receptor Beta Agonist Treatment

Modifies the Hippocampal

Transcriptome in Middle-Aged Ovariectomized Rats.

Front. Cell. Neurosci. 10:149. doi: 10.3389/fncel.2016.00149
Estradiol (E2) robustly activates transcription of a broad array of genes in the hippocampal formation of middle-aged ovariectomized rats via estrogen receptors ( $E R \alpha, E R \beta$, and $G$ protein-coupled ER). Selective ER $\beta$ agonists also influence hippocampal functions, although their downstream molecular targets and mechanisms are not known. In this study, we explored the effects of long-term treatment with ER $\beta$ agonist diarylpropionitrile (DPN, $0.05 \mathrm{mg} / \mathrm{kg} / \mathrm{day}, \mathrm{sc}$.) on the hippocampal transcriptome in ovariectomized, middle-aged (13 month) rats. Isolated hippocampal formations were analyzed by Affymetrix oligonucleotide microarray and quantitative real-time PCR. Four hundred ninety-seven genes fulfilled the absolute fold change higher than $2(\mathrm{FC}>2)$ selection criterion. Among them 370 genes were activated. Pathway analysis identified terms including glutamatergic and cholinergic synapse, RNA transport, endocytosis, thyroid hormone signaling, RNA degradation, retrograde endocannabinoid signaling, and mRNA surveillance. PCR studies showed transcriptional regulation of 58 genes encoding growth factors (Igf2, Igfb2, Igf1r, Fgf1, Mdk, Ntf3, Bdnf), transcription factors (Otx2, Msx1), potassium channels (Kcne2), neuropeptides (Cck, Pdyn), peptide receptors (Crhr2, Oprm1, Gnrhr, Galr2, Sstr1, Sstr3), neurotransmitter receptors (Htr1a, Htr2c, Htr2a, Gria2, Gria3, Grm5, Gabra1, Chrm5, Adrb1), and vesicular neurotransmitter transporters (S/c32a1, S/c17a7). Protein-protein interaction analysis revealed networking of clusters associated with the regulation of growth/troph factor signaling, transcription, translation, neurotransmitter and neurohormone signaling mechanisms and potassium channels. Collectively, the results reveal the contribution of ER $\beta$-mediated processes to the regulation of transcription, translation, neurogenesis, neuromodulation, and neuroprotection in the hippocampal formation of ovariectomized, middle-aged rats and elucidate regulatory channels responsible for DPN-altered functional patterns. These findings support the notion that selective activation of ER $\beta$ may be a viable approach for treating the neural symptoms of E2 deficiency in menopause.

Keywords: hippocampus, rat, ovariectomy, estrogen receptor $\beta$, microarray, PCR, transcriptome, pathway analysis 


\section{INTRODUCTION}

$17 \beta$-estradiol (E2) exerts profound effects in the brain including the hippocampus (Gould et al., 1990). E2 increases dendritic spine density of principal neurons during the estrous cycle (Woolley et al., 1990), modulates both excitatory (Woolley et al., 1997) and inhibitory (Murphy et al., 1998) neurotransmission, enhances long-term potentiation (LTP) (Foy et al., 1999), regulates neurogenesis (Tanapat et al., 1999), and attenuates the innate immune response (Vegeto et al., 2003). E2 improves cognitive performance in adult and middle-aged ovariectomized (OVX) rats (Talboom et al., 2008; Rodgers et al., 2010) and mice (Walf et al., 2008). These effects are mediated by the two canonical intracellular receptors $\mathrm{ER} \alpha, \mathrm{ER} \beta$, and the membrane G protein-coupled estrogen receptor GPER, which are expressed in the hippocampal formation (Shughrue and Merchenthaler, 2000; Brailoiu et al., 2007; Mitterling et al., 2010; Waters et al., 2015). The complex action of these receptors results in sensitive responses of the female hippocampus to the cyclic changes of serum E2 levels.

$\mathrm{ER} \alpha$ and $\mathrm{ER} \beta$ mediate the effects of E2 on both intracellular signaling and gene transcription. They share similar domain organization, and use almost identical DNA binding elements, co-regulators, and transcription machinery (Gronemeyer et al., 2004). The expression of the two receptors is not overlapping (Shughrue et al., 1997), and differences in learning and memory exist between ER knockout (ERKO) mice (Han et al., 2013). ER $\alpha$ KO mice show reduced estrogen responsiveness and impaired hippocampus-dependent memory (Foster et al., 2008). ER $\beta K O$ mice display attenuated hippocampal CA1 LTP and related memory deficits (Day et al., 2005). The phenotypes suggest distinct roles of $E R \alpha$ and $E R \beta$ in estrogen signaling.

Combinations of genetic and pharmacological approaches have been successfully used to dissect the role of $\operatorname{ER} \beta$ in the regulation of hippocampal functions. Activation of ER $\beta$ with a selective agonist WAY-200070 enhances LTP and synaptic plasticity (Liu et al., 2008). E2 improves hippocampus-dependent memory in wild type and ER $\alpha \mathrm{KO}$ mice, but not in ER $\beta \mathrm{KO}$ animals (Liu et al., 2008). Diarylpropionitrile (DPN) improves cognitive performance in wild type, but not in ERßKO mice (Walf et al., 2008). In rats, behavioral studies have shown that DPN evokes anxiolytic effects (Walf and Frye, 2005) and enhances performance in hippocampus-dependent memory tasks (Rhodes and Frye, 2006; Pisani et al., 2016). These studies suggest that ER $\beta$ agonists mimic many basic effects of E2 in the hippocampus and enhance hippocampus-dependent spatial memory (Rhodes and Frye, 2006; Jacome et al., 2010; Pisani et al., 2012, 2016).

Human menopause is characterized by declining levels of E2 that influence the performance of the hippocampal formation (Weber et al., 2013). Symptoms may include anxiety, mild depression, disturbances in contextual fear extinction, impairment of spatial memory and regression of sexual behavior. We have shown that in 13 months old OVX rats the hippocampal transcriptome is highly responsive to timely E2 replacement (Sarvari et al., 2015). In rodent menopause models, ER $\beta$ agonists decrease anxiety (Walf and Frye, 2005; Hughes et al., 2008) and depression (Clark et al., 2012; Suzuki et al., 2013), improve memory (Jacome et al., 2010; Kiss et al., 2012), and modulate fear extinction (Chang et al., 2009; Zeidan et al., 2011). Hence, development of selective ER $\beta$ agonists may result in safe and selective practice of hormone replacement therapy. The present study was devoted to the aforementioned concept with the main task to determine whether long-term DPN treatment of middleaged OVX rats has an impact on the hippocampal transcriptome and to elucidate the putative cellular mechanisms and regulatory channels involved.

\section{MATERIALS AND METHODS}

\section{Experimental Animals}

All experiments were performed with permission from the Animal Welfare Committee of the Institute of Experimental Medicine (IEM, Permission Number: A5769-01) and in accordance with regulations of the European Community (Decree 86/609/EEC). Female Harlan-Wistar rats were purchased from Toxicoop (Budapest, Hungary) and housed on a $12 \mathrm{~h}$ light $/ 12 \mathrm{~h}$ dark cycle in the animal care facility of IEM. The rats were used as breeders and retired at their age of 8 months, and then housed individually for the subsequent months. At their age of 13 months, rats were deeply anesthetized and ovariectomized bilaterally (Sarvari et al., 2010). Afterward, they were kept on phytoestrogen-free diet (Harlan Teklad Global Diets, Madison, WI). Ten days later, Alzet 2004 osmotic minipumps (DURECT, Cupertino, CA) filled either with DPN (3.3 $\mathrm{mg} / \mathrm{ml}$ in propylene-glycol, $n=8$, DPN group) or vehicle only ( $n=8$, control group) were implanted subcutaneously in the scruff of the neck of the animals. This treatment lasted for 29 days providing a dosage of $0.02 \mathrm{mg}$ DPN/animal/day. The same animals and hippocampal samples have been used in a recent PCR study (Sarvari et al., 2014).

\section{Affymetrix Rat Genome 230 PM Strip Arrays}

Hippocampal formations from 16 animals were prepared and total RNA was isolated and analyzed as described previously (Sarvari et al., 2014). RNA quality was measured by capillary electrophoresis using 2100 Agilent Bioanalyzer (Santa Clara, CA, USA) with Nano RNA chips. RNA samples displayed high RNA integrity numbers (RIN > 8.2). Eight samples were examined by oligonucleotide microarray, including amplification, target labeling, hybridization, staining, and scanning steps, which were carried out as described earlier (Sarvari et al., 2015). In brief, 25 ng of total RNA Whole Transcriptome Amplification (WTA) library preparation and amplification for 17 cycles were performed following distributor's (Sigma-Aldrich) recommendations. Eight micrograms cDNA was fragmented by DNAseI and biotinylated by terminal transferase obtained from the GeneChip Mapping 250K Nsp Assay Kit (Affymetrix Inc., Santa Clara, CA, USA). Hybridization, washing, staining and scanning of Affymetrix Rat Genome 230 PM Strip arrays were performed following the manufacturer's recommendations. Scanned images (DAT files) were transformed into intensities (CEL files) using 
the AGCC software (Affymetrix). Data analysis, including GCRMA, statistical and data mining work, were carried out as published earlier (Sarvari et al., 2015). Gene Ontology (GO) term enrichment was analyzed using public functional annotation tools [DAVID Bioinformatics Resources; http://david. abcc.ncifcrf.gov (Huang Da et al., 2009), and KEGG pathway database; http://www.genome.jp/kegg]. Annotation clusters were ranked by their score number, termed enrichment score, calculated from the modified Fisher's exact $p$-value of each GOterm. Putative protein-protein interactions were evaluated by the web-based STRING 10 platform (http://string-db.org).

\section{Quantitative Real-Time PCR}

Custom TaqMan microfluidic cards (Applied Biosystems, Foster City, CA, USA) were designed to study mRNA expression by real-time PCR. Sixteen samples were examined. One microgram of total RNA was used for reverse transcription. Reverse transcription and PCR were carried out by using Applied Biosystems' High Capacity cDNA Reverse Transcription Kit and TaqMan Universal PCR Master Mix II, respectively. The ViiA7 RUO 1.2.1 (Applied Biosystems) software and relative quantification against calibrator samples $(\Delta \Delta \mathrm{Ct})$ were used for data evaluation. Glyceraldehyde-3-phosphate dehydrogenase (Gapdh) and hypoxanthine guanine phosphoribosyl-transferase (Hprt) were used as housekeeping genes. Expression of these genes did not vary among experimental groups. A computed internal control corresponding to the geometric mean of cycle threshold (Ct) values of Gapdh and Hprt was used for Ct calculation. PCR data evaluation were performed as described previously (Sarvari et al., 2014).

\section{RESULTS}

\section{Effect of Long-Term DPN Administration on Uterus Weight}

Middle-aged, OVX rats received DPN at a dose of $20 \mu \mathrm{g} /$ day, subcutaneously via osmotic minipump for 29 days. At the end of treatment, the potential proliferative threat on the uterus was checked. The uterus weight of vehicle- and ER $\beta$ agonist-treated rats were $205 \pm 43.2$ and $163 \pm 30.0 \mathrm{mg}$, respectively, indicating that DPN at this dose and treatment time did not induce cell proliferation in the uterus.

\section{Changes of the Hippocampal Transcriptome in Response to Chronic DPN Treatment \\ Microarray Study}

Differential expression was studied in the hippocampal formation by comparing vehicle- and ER $\beta$ agonist-treated animals. We found that chronic treatment with DPN evoked significant changes in the transcriptome. We considered a gene regulated if the change of its transcription, i.e., the modulus of its fold change (mFC), exceeded 2. Symbols and description of regulated genes are listed in Supplementary Table 1. Four hundred ninety-seven genes fulfilled the
$\mathrm{mFC}>2.0$ selection criterion. From these, 370 were activated (Supplementary Table 2).

The top 59 upregulated and 11 downregulated genes, which satisfied the mFC > 2.7 criterion, were listed in Table 1. DPN robustly activated $(\mathrm{FC}>4)$ the transcription of 18 genes including transthyretin (Ttr), claudin 2 (Cldn2), klotho $(K l)$, insulin-like growth factor-binding protein 2 (Igfbp2), secretoglobin (Scgb1c1), folate (Folr1), and prolactin (Prlr) receptors, sclerostin domain containing (Sostdc1), small nuclear ribonucleoprotein polypeptide G (Snrpg), prostaglandin D2 synthase (Ptgds), insulin-like growth factor 2 (Igf2), malectin (Mlec), SEC63 homolog (Sec63), membrane frizzled-related protein $(M f r p)$, spectrin beta, non erythrocytic 4 (Sptbn4), midkine $(M d k)$, angiotensin I converting enzyme (Ace), and poliovirus related receptor 1 (Pvrl). The single robustly suppressed target gene $(\mathrm{FC}<0.25)$ was stem-loop binding protein $(S l b p)$.

\section{Heat Map Analysis}

The heat map represents mRNA expression of the top 70 differentially expressed genes in the hippocampal formation of vehicle treated (M-OVX) and DPN-treated (M-OVX+DPN) animals (Figure 1). The heat map demonstrated that the hippocampal transcriptome robustly responded to long-term DPN treatment. The majority of transcriptional changes was activation. The color-coded visualization of mRNA expression levels displayed only small variability within the experimental groups.

\section{Functional Annotation of DPN-Regulated Genes}

Pathway analysis and functional annotation clustering of DPNregulated genes were performed on web-based platforms, KEGG, and DAVID v6.7 bioinformatics tool, respectively. KEGG analysis (Table 2) identified terms related to neurotransmission including glutamatergic synapse (Gng12, Dlgap1, Cacna1a, Shank2, Gls, Gnbr, Kcnj3, Grm1, Grm8), cholinergic synapse (Chrm4, Gng12, Pik3ca, Fos, Cacnala, Chrm1, Gnbr, Kcnj3), RNA transport (Tpr, Srrm1, Eif3d, Eif4g1, Thoc2, Eif3e, Upf3a, Nupl1, Pabpc1, Ranbp2), endocytosis, thyroid hormone signaling pathway (Hifla, Pik3ca, Med1, Ncor1, Slc9a1, Crebbp, Pfkfb2, Atp2a2), RNA degradation (Dhx36, Cnot6l, Edc4, Pabpc1, Ddx6, Lsm7), retrograde endocannabinoid signaling (Gng12, Cacnala, Mgll, Mapk10, Gnbr, Kcnj3, Grm1), and mRNA surveillance pathway (Papolg, Pabpn1, Srrm1, Upf3a, Cpsf3, Pabpc1). By the use of STRING program, putative interactions of certain proteins encoded by the DPN-regulated genes, obtained from the KEGG pathway analysis, were revealed and plotted (Supplementary Figure 1).

Another functional annotation tool (DAVID) identified 12 clusters with high enrichment score (ES), such as membrane-enclosed lumen $(\mathrm{ES}=4.39)$, mRNA metabolic process (3.16), protein transport (2.24), nuclear mRNA splicing (2.18), regulation of transcription (1.92), fatty acid transport (1.47), regulation of carbohydrate metabolism (1.45), nucleotide binding (1.44), potassium channel complex (1.41), macromolecular complex assembly (1.41), vesicle 
TABLE 1 | List of DPN-regulated genes in the hippocampus.

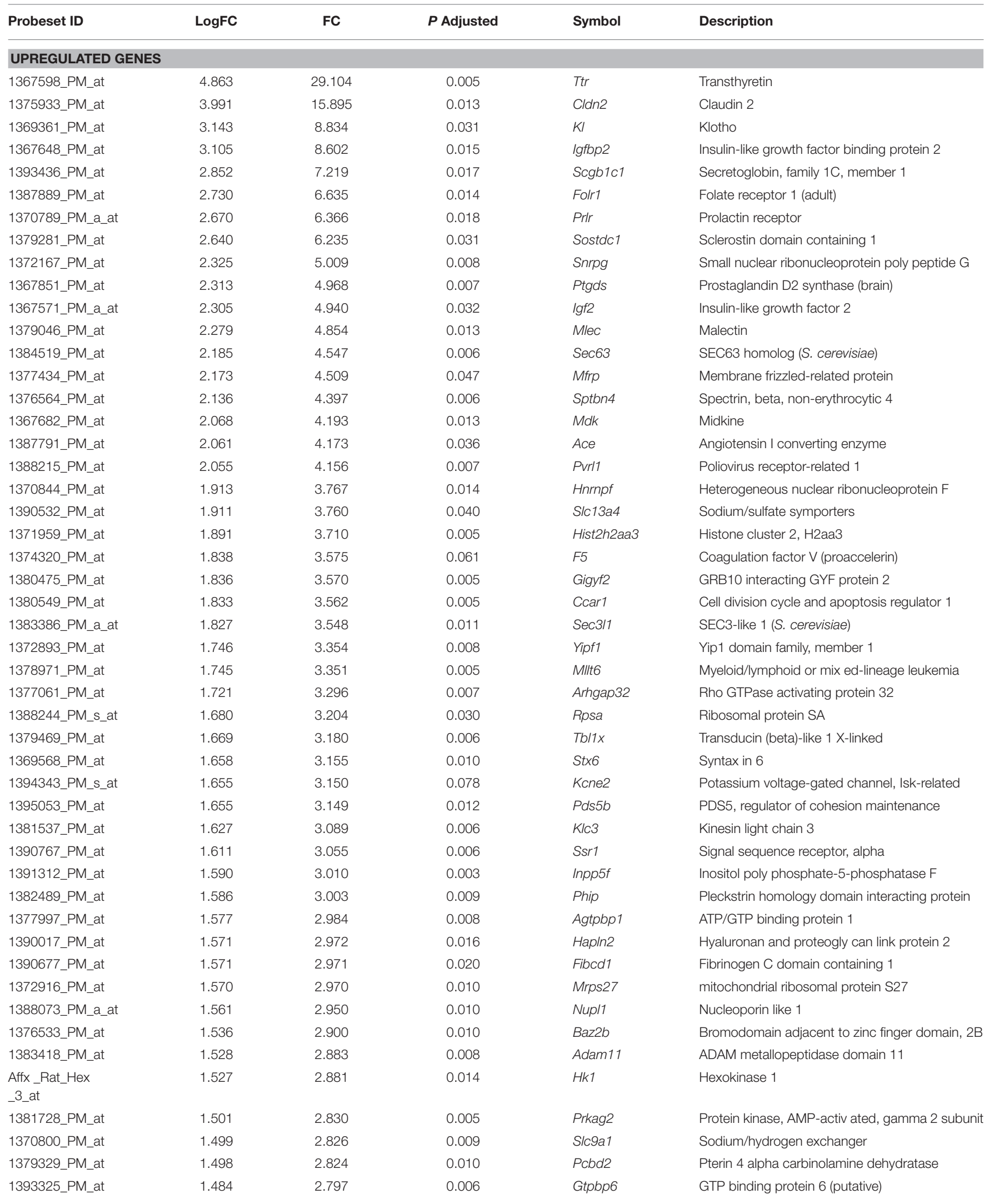


TABLE 1 | Continued

\begin{tabular}{|c|c|c|c|c|c|}
\hline Probeset ID & LogFC & FC & $P$ Adjusted & Symbol & Description \\
\hline 1375149_PM_at & 1.483 & 2.796 & 0.005 & Lrrc4b & Leucine rich repeat containing 4B \\
\hline 1395913_PM_at & 1.482 & 2.794 & 0.006 & Acbd4 & Acy I-CoA binding domain containing 4 \\
\hline 1371335_PM_at & 1.481 & 2.792 & 0.010 & Atp5l & ATP synthase, $\mathrm{H}+$ transporting, mitochondrial Fo \\
\hline 1388568_PM_at & 1.476 & 2.782 & 0.024 & Eif3d & Eukaryotic translation initiation factor 3 , subunit \\
\hline 1374172_PM_at & 1.474 & 2.778 & 0.049 & Col8a2 & Collagen, type VIII, alpha 2 \\
\hline 1368729_PM_a_at & 1.451 & 2.734 & 0.009 & Adcyap1r1 & $\begin{array}{l}\text { Adenylate cyclase activating poly peptide } 1 \\
\text { receptor }\end{array}$ \\
\hline 1388396_PM_at & 1.450 & 2.731 & 0.007 & Stk25 & Serine/threonine kinase 25 \\
\hline 1398487_PM_at & 1.443 & 2.719 & 0.006 & $P b \times 1$ & Pre-B-cell leukemia homeobox 1 \\
\hline 1388531_PM_at & 1.442 & 2.717 & 0.024 & Pgrmc2 & Progesterone receptor membrane component 2 \\
\hline 1383920_PM_at & 1.442 & 2.716 & 0.005 & Amt & Aminomethyltransferase \\
\hline \multicolumn{6}{|c|}{ DOWNREGULATED GENES } \\
\hline 1398355_PM_at & -1.449 & 0.366 & 0.025 & Trpm7 & $\begin{array}{l}\text { Transient receptor potential cation channel, } \\
\text { subfamily M }\end{array}$ \\
\hline 1371243_PM_at & -1.451 & 0.366 & 0.011 & Grm8 & Glutamate receptor, metabotropic 8 \\
\hline 1383192_PM_at & -1.452 & 0.366 & 0.006 & Spast & Spastin \\
\hline 1388755_PM_at & -1.461 & 0.363 & 0.011 & Sec23a & Sec23 homolog A (S. cerevisiae) \\
\hline 1395461_PM_at & -1.493 & 0.355 & 0.005 & Apc2 & Adenomatosis polyposis coli 2 \\
\hline 1383172_PM_at & -1.507 & 0.352 & 0.007 & Ranbp2 & RAN binding protein 2 \\
\hline 1389479_PM_at & -1.569 & 0.337 & 0.009 & KIf3 & Kruppel-like factor 3 (basic) \\
\hline 1381859_PM_at & -1.607 & 0.328 & 0.018 & Fam91a1 & Family with sequence similarity 91 , member A1 \\
\hline 1388689_PM_at & -1.682 & 0.312 & 0.007 & Aсур2 & Acylphosphatase 2, muscle type \\
\hline 1390509_PM_a_at & -1.913 & 0.265 & 0.013 & Mrpl51 & Mitochondrial ribosomal protein L51 \\
\hline 1391387_PM_s_at & -2.186 & 0.220 & 0.020 & Slbp & Stem-loop binding protein \\
\hline
\end{tabular}

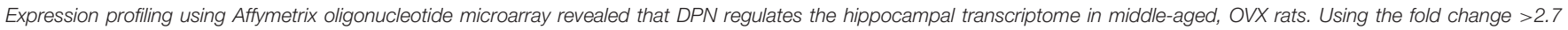
selection criterion, the list of microarray data contains 59 up- and 11 downregulated genes.

coating (1.39), and DNA-dependent transcription (1.3) clusters (Supplementary Table 3).

\section{Quantitative Real-Time PCR Study of DPN-Regulated Genes}

We applied quantitative real-time PCR to confirm DPNdependent regulation of selected genes and to get further insight to the impact of DPN on neurotransmission. We selected 21 genes from the microarray gene list to confirm regulation and 37 additional genes which are associated with neurotransmitter and neuropeptide signaling. Selected genes and changes in their mRNA expression are summarized in Table 3. The PCR study revealed robustly and moderately regulated genes. Robustly activated genes ( $\mathrm{RQ}>4.0 ; 17$ genes) included Sostdc1, Ttr, Kl, Prlr, Slco1a5, Mfrp, Aqp1, Otx2, Cldn2, Igfbp2, Folr1, Igf2, Ace, Crhr2, Htr2c, Slc13a4, and Enpp2. Group of moderately activated genes $(4>\mathrm{RQ}>1.2 ; 28$ genes) contained Cdkn1c, Kcne2, Cox8b, Fgf1, Mdk, Sfrp1, Msx1, Anxa2, Ptgds, A2m, Aldh1a2, Mrc1, Slc12a2, Cdkn1a, Htr2a, Gpx1, Gria2, Oprm1, Igf1r, Inpp5f, Ntf3, Gnrhr, Chrm5, Nr3c1, Grm5, Gria3, Gphn, Gabra1. The group of downregulated genes coded for neuropeptides (Pdyn, Cck), neuropeptide receptors (Sstr1, Sstr3, Galr2), neurotransmitter receptors (Htr1a, Adrb1), vesicular transporters (Slc17a7, Slc32a1), neurotrophic factor (Bdnf), and others (Gad1, Apoe, Atp2b4). Importantly, DPN-dependent regulation of the 21 selected genes including Sostdc1, Ttr, Kl, Prlr, Slco1a5, Mfrp, Aqp1, Otx2, Cldn2, Igfbp2, Folr1, Igf2, Ace, Htr2c, Slc13a4, Enpp2, Kcne2, Mdk, Ptgds, Inpp5f, A2m was confirmed by the PCR study.

\section{Predicted Networking of Proteins Encoded by DPN-Regulated Genes}

Altogether, we identified 534 DPN-regulated genes by expression profiling. We searched for interactions among proteins encoded by these genes using the STRING 10 platform. At high confidence level (0.72), STRING predicted a large number of putative interactions and clusters composed of more than four elements indicating that DPN may modulate multiple regulatory mechanisms involved in hippocampal functions (Supplementary Figure 2). STRING 10 analysis performed at the highest confidence value (0.9) and filtering clusters for having more than 3 interacting proteins, predicted interactions among 95 proteins (Figure 2). These 95 proteins form functional clusters that may also network with each other. Five major clusters emerged from the analysis. Cluster 1 contained 31 proteins that are associated with transcription, mRNA metabolism, splicing, and translation. This group networks with cluster 2 comprised of 26 intracellular signaling molecules and regulators of transcription. The individual cluster 3 had five potassium channel components. Cluster 4 is linked to cluster 2 and 5, and 


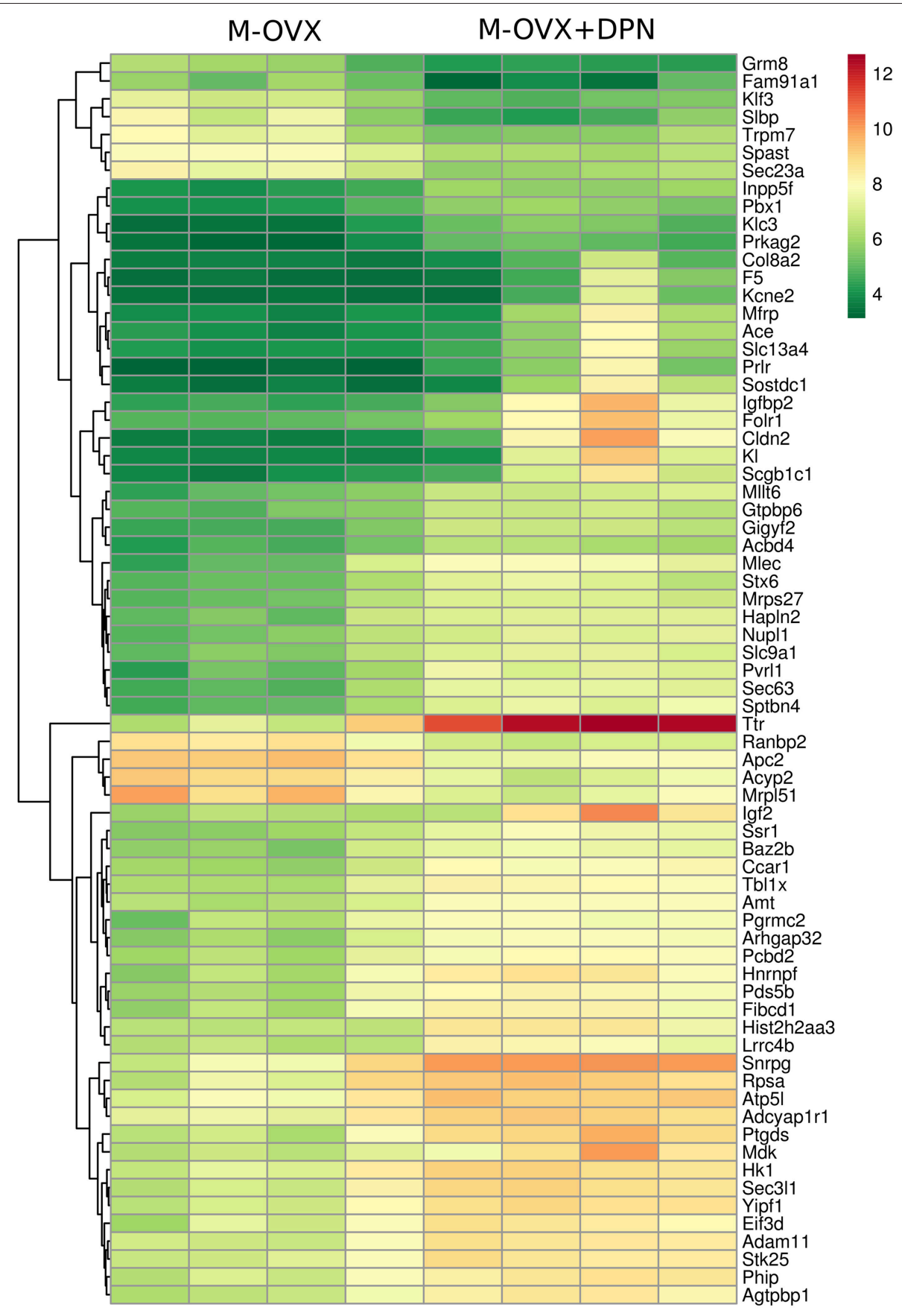

FIGURE 1 | Heat map. It depicts 70 differentially expressed genes in the hippocampus of middle-aged OVX rats treated for 29 days with vehicle or ER $\beta$ agonist DPN, respectively. Rows represent DPN-regulated probe sets with corresponding gene symbols displayed on the right side of the figure. Transcription level of each probe is color coded, the continuous color key is displayed in the upper right corner. Individual hippocampal samples of four vehicle (M-OVX)- and four DPN

$(\mathrm{M}+\mathrm{OVX}+\mathrm{DPN})$-treated animals are shown in columns.

included 13 growth/troph factors and related proteins. Cluster 5 contained 20, mostly G protein-coupled neurotransmitter and neuropeptide receptors and neuropeptides. This cluster is wired to cluster 4 via Pik3ca (and Trio).

A separate STRING analysis of down-regulated genes was performed to take into account of transcriptional suppression
(Figure 3). Predicted interactions among proteins encoded by suppressed genes showed Fos as the hub of the network. One of the clusters was composed of proteins that are responsible for neuropeptide (Pdyn, CCK, Sstr1, Sstr3, Bdkrb2) and neurotransmitter (Htr1a, Grm8) signaling mechanisms. Another cluster was related to neurotransmitter synthesis (Gad1, Gls) and 
TABLE 2 | Pathway analysis.

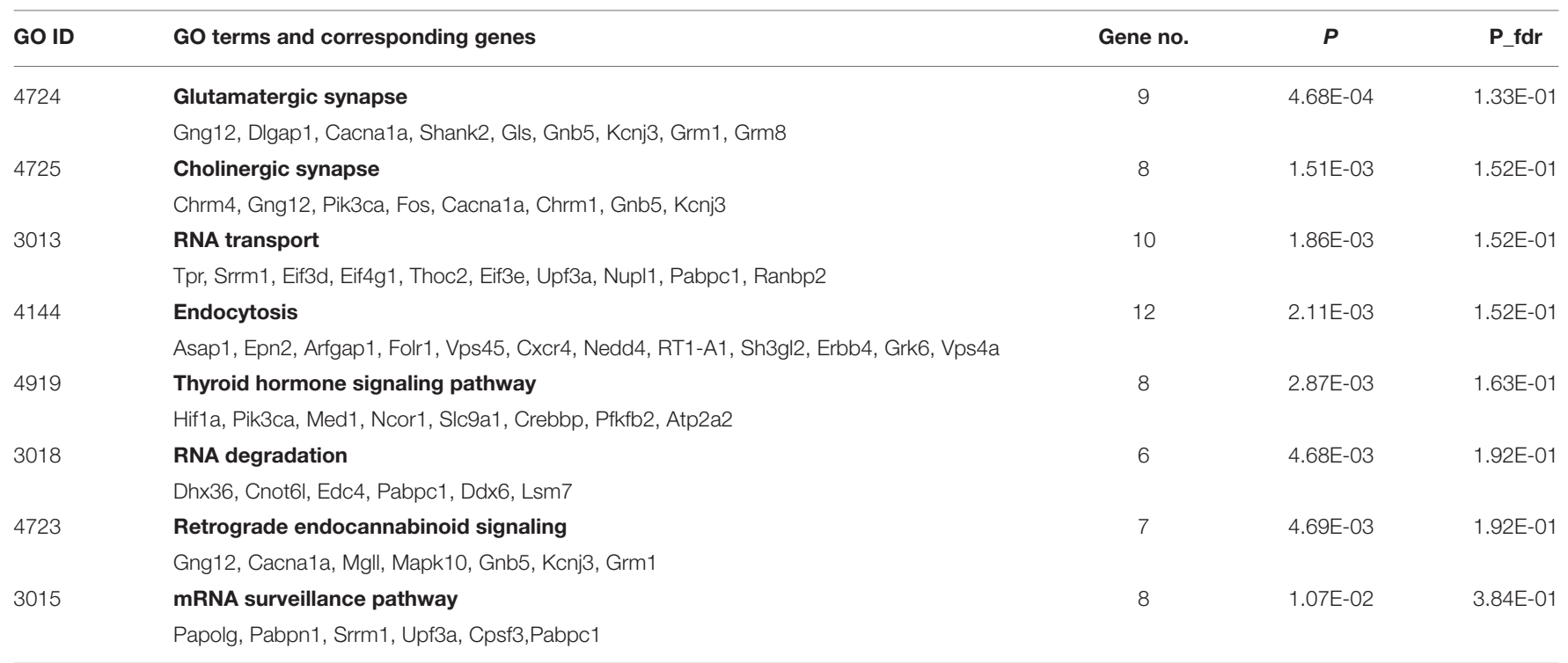

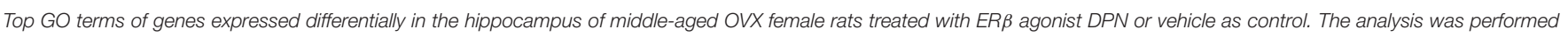
on the web-based KEGG platform. Terms were ranked based on their fdr values. Genes are listed at each GO term. Fdr, false discovery rate.

vesicular transport (Slc17a7, Slc32a1). Other clusters serve the initiation of transcription via Fos.

\section{DISCUSSION}

Exploration of selective ER $\beta$ agonists has been pursued by the academia and the pharmaceutical industry (Sun et al., 2003; Liu et al., 2008; Clark et al., 2012) since the discovery of the second ER (Kuiper et al., 1996). Molecular, morphological and behavioral studies demonstrated beneficial impact of ER $\beta$ agonists on hippocampal functions including anxiety, learning and memory, but the underlying molecular mechanisms remain poorly understood. To explore the impact of ER $\beta$ agonists on hippocampal gene expression, we characterized DPN-evoked transcriptional changes in OVX, middle-aged female rats. We found that in this menopausal model, longterm DPN treatment alters hippocampal gene expression, activates several growth/troph factors, modifies transcription and translation, modulates neurotransmitter and neuropeptide signaling mechanisms and exerts neuroprotective effects.

\section{Previous Expression Profiling Studies in the Rodent Hippocampus}

Estrogenic regulation of the hippocampal transcriptome has already been investigated in mice (Han et al., 2013). Comparison of basal and E2-induced gene expression profiles in wild-type and ERKO mice has clarified the role of $\operatorname{ER} \beta$. $\operatorname{ER} \beta$ exerts a regulatory role on ER $\alpha$-mediated gene expression and can substitute ER $\alpha$ in the presence of higher levels of E2. The list of the top 30 genes regulated by $\mathrm{E} 2$ in the hippocampus of middle-aged ER $\alpha \mathrm{KO}$ mice has been published (Han et al., 2013). Importantly, we found 12 overlapping top ER $\beta$-regulated genes in the mouse and rat hippocampus including Ttr, Otx2, F5, Sostdc1, Folr1, Cldn2, Kl, Slc13a4, Enpp2, Ace, Kcne2, and Igf2.

We have previously examined the effect of treatments with various ER agonists on the innate immune system of the hippocampus in the same model (Sarvari et al., 2014). The study revealed that DPN exerts many overlapping effects with $\mathrm{E} 2$ and ER $\alpha$ agonist $16 \alpha$-estradiol lactone, but there are clear differences. In addition, it supports our previous finding that estrogens regulate neuroinflammatory genes via $\mathrm{ER} \alpha$ and $\operatorname{ER} \beta$ (Sarvari et al., 2011). In another study, we have explored the impact of E2 replacement on the rat hippocampal transcriptome and identified E2 target genes (Sarvari et al., 2015). Comparison with DPN-regulated genes show that $38 \%$ of the top E2 target genes also respond to chronic DPN treatment. Overlapping genes include Ttr, Kl, Cldn2, Prlr, Sostdc1, F5, Igf2, Igfbp2, Slc13a4, Folr1, Htr2c, Col8a2, Mfrp, Otx2, Ace, Mdk, Enpp2, Slco1a5, Ptgds, Kcne2, Scgb1c1, A2m, Aqp1. This result demonstrates that long-term DPN treatment partly mimics the genomic effects of E2 replacement.

\section{Chronic DPN Administration Affects Neurotransmitter Signaling GABA}

GABAergic interneurons control local neuronal circuits in the hippocampus (Freund and Buzsaki, 1996). Six $\mathrm{GABA}_{\mathrm{A}}$ receptor $\alpha$ subunits $(\alpha 1-\alpha 6)$ take part in the formation of $\mathrm{GABA}_{\mathrm{A}}$ complexes. $\alpha 1, \alpha 2$, and $\alpha 4$ are found in all sectors of the hippocampus (Wisden et al., 1992). GABA A receptor alpha1 subunit mRNA expression was found in CA1 and CA3 pyramidal neurons and in granule cells (Wisden et al., 1992). Strong $\alpha 1$ immunostaining of GABAergic neurons was also characteristic. All parvalbumin (PV) and half of calretinin interneurons express $\alpha 1$, but calbindin, cholecystokinin (CCK) and VIP interneurons 
TABLE 3 | PCR Results.

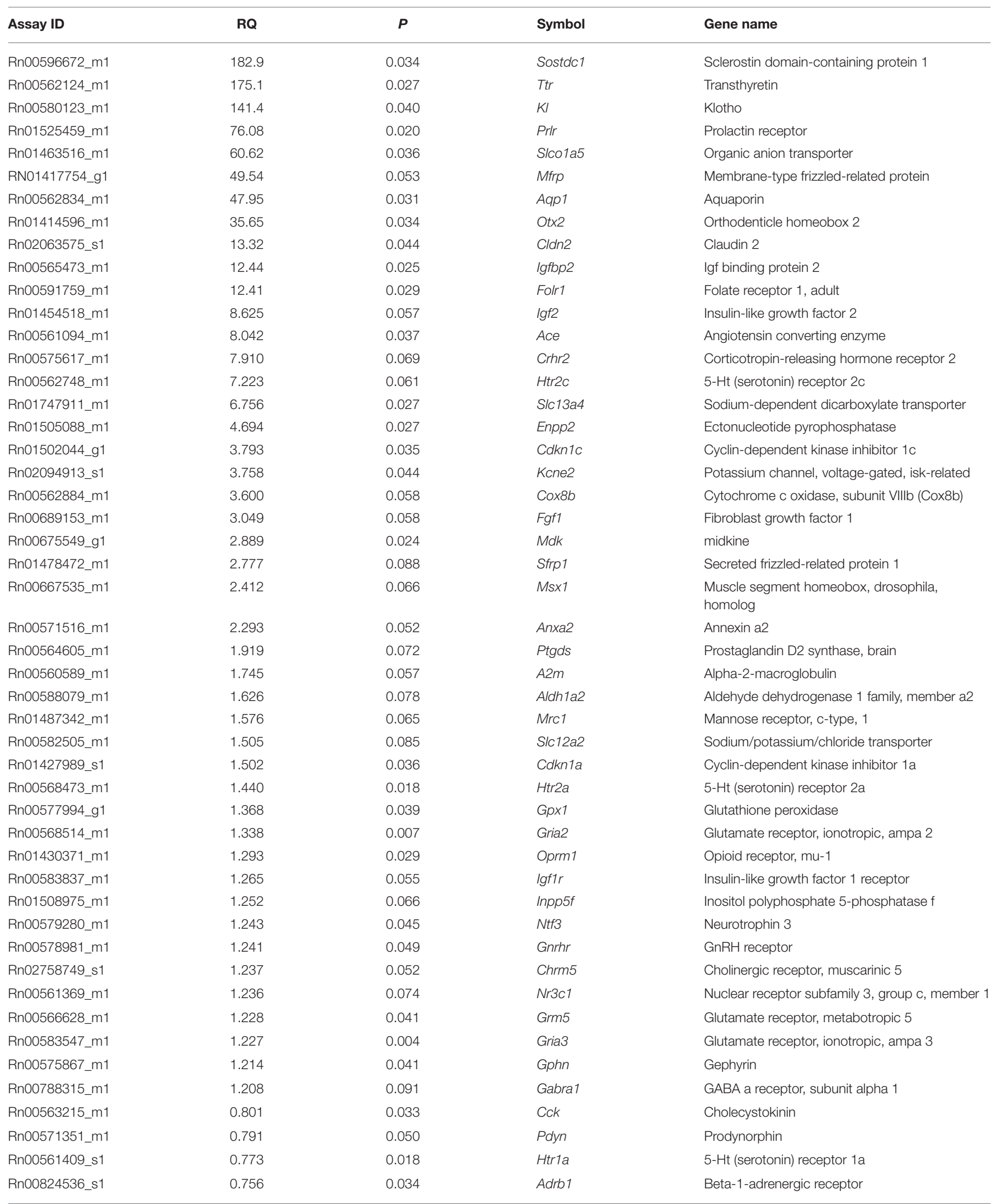


TABLE 3 | Continued

\begin{tabular}{lllll}
\hline Assay ID & RQ & $\boldsymbol{P}$ & Symbol & Gene name \\
\hline Rn00593680_m1 & 0.748 & 0.026 & Apoe & Apolipoprotein E \\
Rn01483363_m1 & 0.720 & 0.036 & Atp2b4 & $\begin{array}{l}\text { Atpase, ca(2+)-transporting, plasma membrane, } \\
\text { Rn00690300_m1 }\end{array}$ \\
Rn00695901_g1 & 0.688 & 0.010 & Gad1 & 67 kda glutamic acid decarboxylase - gad67 \\
Rn00824654_m1 & 0.661 & 0.067 & Galr2 & Galanin receptor 2 \\
Rn02531967_s1 & 0.600 & 0.002 & Slc32a1 & GABA vesicular transporter \\
Rn02134439_s1 & 0.580 & 0.003 & Bdnf & Brain-derived neurotrophic factor \\
Rn02532012_s1 & 0.576 & 0.002 & Sstr3 & Somatostatin receptor 3 \\
Rn01462431_m1 & 0.463 & 0.029 & Sstr1 & Somatostatin receptor 1 \\
& 0.366 & 0.012 & Slc17a7 & Vesicular glutamate transporter 1 - vglut1
\end{tabular}

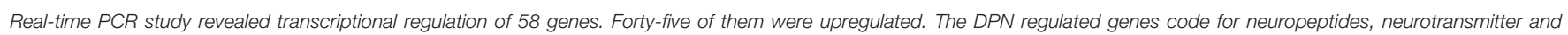
neurohormone receptors, growth hormones, transcription factors, and transporters. $R Q$, relative quantity.

do not (Gao and Fritschy, 1994). We found that long-term ER $\beta$ agonist treatment upregulates Gabra1 which encodes the $\alpha 1$ receptor subunit. Gephyrin, a scaffold protein anchors $\mathrm{GABA}_{\mathrm{A}}$ receptors to postsynaptic cytoskeleton. The E domain of gephyrin directly binds intracellular residues of 360-374 of $\alpha 1$ (Mukherjee et al., 2011). DPN also upregulates Gphn.

Most GABAergic neurons utilize both isoforms of glutamic acid decarboxylase (GAD) in the hippocampal formation (Houser and Esclapez, 1994). GAD67 (GAD1) is spread evenly in the cell, but GAD65 is localized to axon terminals indicating that the former isoform produces GABA for basic cellular processes, the latter for neurotransmission. Estrogenic regulation of the expression of GAD isoforms at mRNA and protein levels has been published (Nakamura et al., 2004). We showed downregulation of Gad1 after chronic DPN treatment. At axon terminals of inhibitory neurons, vesicular inhibitory amino acid transporters (VIAAT) fill synaptic vesicles with GABA. The transporter protein is highly expressed in the pyramidal and granular layers of the hippocampus (Chaudhry et al., 1998). VIAAT is coded by Slc32a1, which was downregulated by DPN. These alterations predict a decrease in the inhibitory tone within the hippocampal formation after long-term DPN treatment.

\section{Glutamate}

Class I metabotropic glutamate receptors show a distinct pattern of expression in the hippocampus. Metabotropic glutamate receptor 1 (mGluR1) is mainly expressed in granule cells and CA3 pyramidal neurons while mGluR5 is highly expressed in all subfields of the rat hippocampus (Fotuhi et al., 1994). We demonstrated that chronic DPN treatment enhances transcription of Grm1 and Grm5. Estrogenic regulation of AMPA receptors at protein level has already been described in the rat hippocampus (Waters et al., 2009). We found that DPN increases mRNA expression of Gria2 and Gria3 coding for GluR2 and GluR3 subunits of the AMPA receptor, respectively.

Glutaminase converts glutamine to glutamate in glutamatergic neurons. Glutaminase IR is found in cell bodies of principal neurons and sparsely, in axon terminals in the rat hippocampus (Altschuler et al., 1985). Glutaminase is also localized to astrocytes (Cardona et al., 2015). We observed that DPN decreases glutaminase mRNA expression. From the three known vesicular glutamate transporters (vGLUT1-3), vGLUT1 is the main subtype expressed in the hippocampus (Fremeau et al., 2004). It packs glutamate into synaptic vesicles of the glutamatergic axon terminals. DPN significantly inhibits transcription of Slc17a7 which codes for vGLUT1. These findings indicate that long-term DPN treatment decreases the release pool of glutamate in the hippocampus.

\section{Serotonin}

The $\mathrm{HT}_{1 \mathrm{~A}}$ receptor is abundantly expressed in all CA sectors and the dentate gyrus of rat hippocampus (Wright et al., 1995). DPN modestly downregulates Htr1a. The two $5-\mathrm{HT}_{2}$ receptors, $\mathrm{HT}_{2 \mathrm{~A}}$ and $\mathrm{HT}_{2 \mathrm{C}}$ show distinct expression patterns in the rat hippocampus (Pompeiano et al., 1994). $\mathrm{HT}_{2 \mathrm{~A}}$ is expressed in the CA3 sector, $\mathrm{HT}_{2 \mathrm{C}}$ is expressed in the pyramidal cell layer of CA3, the stratum oriens of CA1 and CA2. We showed that both receptor genes (Htr2a, Htr $2 c$ ) are activated in response to DPN. Activation of $\mathrm{HT}_{2 \mathrm{~A}}$ receptors has been shown to decrease the expression of BDNF in the granule cell layer without affecting the CA subfields (Vaidya et al., 1997). $\mathrm{HT}_{2 \mathrm{~A}}$ receptor is in colocalization with NR1 and GluR2 glutamate receptors residing in dendrites of dentate gyrus neurons. To a lesser extent, the receptor is also expressed in GABAergic interneurons of the dentate gyrus.

\section{Acetylcholine}

Muscarinic acetylcholine receptors are $G$ protein-coupled receptors. $M_{1}$ mediates primarily the effect of acetylcholine on cognition, plasticity and neuronal excitability (Wei et al., 1994). It has been suggested that expression of muscarinic receptor subtypes depends on serum E2 levels (Cardoso et al., 2010). In concert of this, we found that Chrm1 and Chrm5, which encode $M_{1}$ and $M_{5}$, respectively, are upregulated by DPN. $M_{5}$ is expressed in the hippocampus, especially in pyramidal cells of CA1 (Vilaro et al., 1990). 


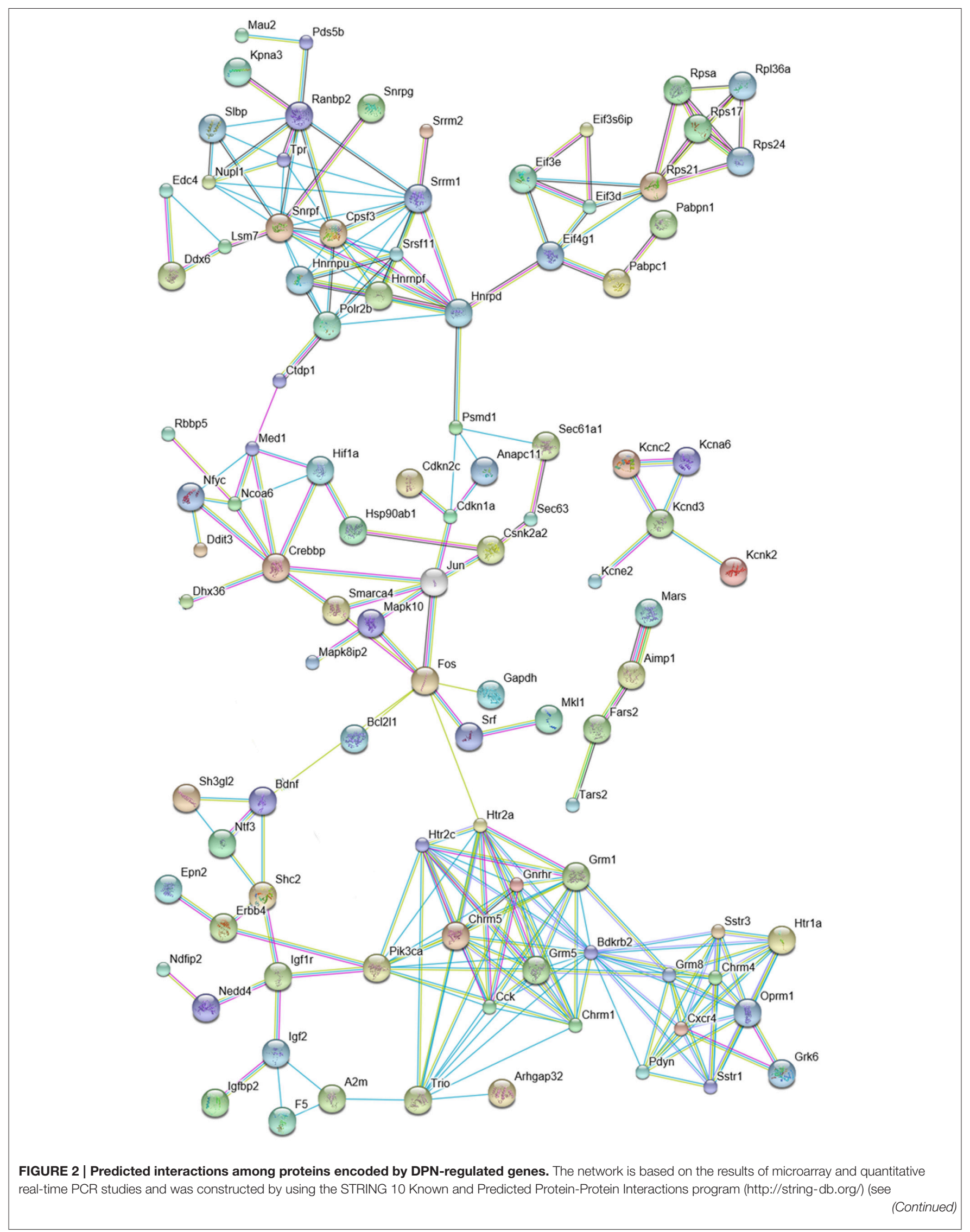




\section{FIGURE 2 | Continued}

Supplementary Figure 2). Analysis was performed at high confidence value (0.9), non-interacting elements were excluded. Selected protein clusters of the network are depicted. Cluster 1: mRNA metabolism, splicing and translation; Cluster 2: regulation of transcription (red elliptic line highlights the relationship of Crebbp, Mapk8p2, Mapk10, Fos and Jun); Cluster 3: components of potassium channels; Cluster 4: growth/troph factors; Cluster 5: peptides, neurotransmitter and neuropeptide receptors.

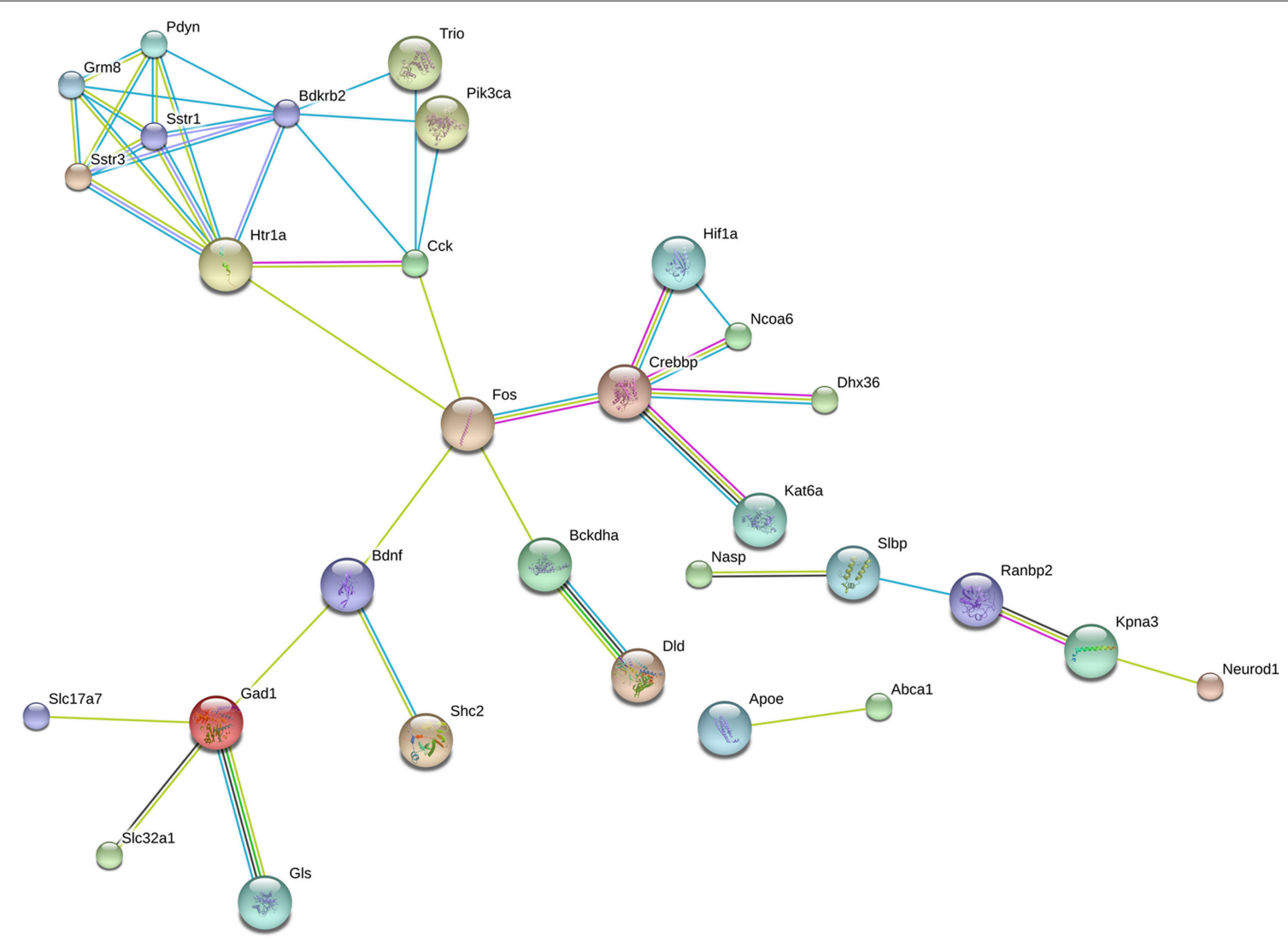

FIGURE 3 | Predicted interactions among proteins encoded by downregulated genes. Network composed of proteins whose coding genes were downregulated by long-term DPN treatment. STRING analysis, high confidence value (0.9).

\section{Catecholamines}

$\beta 1$-adrenoceptors are expressed in the brain including CA1, CA3, and dentate gyrus of the hippocampus (Vizi and Kiss, 1998; Paschalis et al., 2009). Beta 1 adrenergic receptor (Adrb1) expression has been described in somatostatin and PV interneurons of the CA1 and CA3 regions (Cox et al., 2008). Long-term DPN treatment slightly downregulates Adrb1.

\section{Modulation of Peptidergic Signaling Cholecystokinin}

The gut peptide CCK is also synthesized in the brain (Innis et al., 1979). The rat hippocampus contains a great number of CCK neurons predominantly located in CA1-2 regions and dentate gyrus (Savasta et al., 1988). CCK-containing terminals are located mainly in the CA1 and dentate gyrus (Handelmann et al., 1981). CCK interneurons represent 10\% of GABAergic cells in the hippocampus (Kosaka et al., 1985). We found that DPN suppresses mRNA expression of Cck. The finding is in agreement with the decreased GABAergic tone seen after chronic DPN administration.

\section{Prodynorphin}

Prodynorphin is a precursor of multiple opioid peptides including dynorphin A. After proprotein convertase cleavage, released peptides are stored in large dense-core vesicles in synaptic terminals. Dynorphins, localized primarily to dental granule cells (McGinty et al., 1983), modulate mossy fiber signaling via presynaptic receptors (Weisskopf et al., 1993). We showed that DPN downregulates Pdyn mRNA expression.

\section{Angiotensin II}

Angiotensin II is produced by angiotensin converting enzyme (ACE) from angiotensin I. The rat hippocampus contains high level of angiotensin II (Sirett et al., 1981). Angiotensin II excites CA1 pyramidal cells by disinhibition (Haas et al., 1980). 
Upregulation of Ace is likely to increase the level of angiotensin II after DPN treatment in the hippocampus.

\section{Somatostatin Receptors}

Somatostatin receptor (SSTR) subtypes show wide, distinct but partially overlapping expression in the rat brain including the hippocampus (Kong et al., 1994; Senaris et al., 1994). Somatostatin controls excitatory neurotransmission in the hippocampus via SSTR1 (Cammalleri et al., 2009). SSTR3 mRNA expression has also been reported in the hippocampus (Kong et al., 1994). The receptor protein is associated with cilia of neurons located in the dentate gyrus and CA sectors (Handel et al., 1999). Both Sstr1 and Sstr3 are downregulated by DPN.

\section{$\mu$-Opioid Receptor}

Opioids primarily target interneurons in the hippocampal formation (Zieglgansberger et al., 1979). Accordingly, $\mu$-opioid receptor IR is localized to multipolar cells in the granular and pyramidal cell layers. High $\mu$-receptor mRNA expression was observed exclusively in GABAergic interneurons (Stumm et al., 2004), and only those that innervate pyramidal cell bodies express $\mu$-opioid receptors (Svoboda et al., 1999). Estrogenic regulation of the receptor has been suggested (Martini et al., 1989). We found that DPN modestly activated transcription of Oprm1.

\section{Prolactin Receptor}

Prolactin receptor (PRL-R) is expressed throughout the rat brain (Bakowska and Morrell, 1997; Pi and Grattan, 1998), but the amount of PRL-R mRNA is low in the cerebral cortex (Nagano and Kelly, 1994). We observed robust activation of Prlr in the hippocampus after DPN treatment. Prolactin exerts protective effects on the hippocampus against excitotoxicity (Morales et al., 2014) and increases the number of precursor cells (Walker et al., 2012). In PRL-R KO mice, there was an $80 \%$ decrease in the number of hippocampus-derived neurospheres and the animals showed learning and memory deficits (Walker et al., 2012). Prolactin has been shown to prevent the decrease of neurogenesis evoked by chronic stress (Torner et al., 2009). Of note, prolactin is synthesized in the rat hippocampus independently from the anterior pituitary (Emanuele et al., 1992).

\section{Gonadotropin Releasing Hormone Receptor}

Gonadotropin releasing hormone $(\mathrm{GnRH})$ receptor is expressed in the rat hippocampus (Badr and Pelletier, 1987). GnRH receptors are localized to pyramidal cells of CA1, CA3, and granule cells of the dentate gyrus, respectively (Jennes et al., 1995). Expression of GnRH receptor varies during the estrous cycle, with highest expression in proestrous (Savoy-Moore et al., 1980). We found increased mRNA expression of Gnrhr after DPN administration. GnRH administration has been reported to change the electrophysiological properties of CA1 neurons (Wong et al., 1990) and regulate spine density in the hippocampus (Prange-Kiel et al., 2008).

\section{Galanin Receptors}

Two galanin receptor (GalR) subtypes mediate the protective and trophic effects of galanin in the hippocampus. GalR1 and GalR2 are predominantly expressed in the CA1 subfield and the dentate gyrus, respectively (Gustafson et al., 1996; Depczynski et al., 1998). The hippocampus receives galaninergic innervations from the septum-basal forebrain complex (Melander et al., 1985). DPN downregulates Galr2 in the hippocampus. Galanin receptor 2 interacts with neuropeptide Y Y1 receptor in the dentate gyrus and contributes to an antidepressant effect (Narvaez et al., 2015).

\section{Corticotropin-Releasing Hormone Receptor 2}

Corticotropin-releasing hormone $(\mathrm{CRH})$ receptors are found in the rat hippocampus (Van Pett et al., 2000). The robust downregulation of its expression has recently been reported in rat hippocampus under chronic stress paradigm (Li et al., 2013). We found that DPN enhances mRNA expression of Crhr2.

\section{PACAP Receptor 1}

$\mathrm{PAC}_{1}$, one of the three receptors for adenylate cyclase activating polypeptide (PACAP), is expressed in the hippocampus (Zhou et al., 2000). PACAP regulates phosphorylation of AMPAR primarily via $\mathrm{PAC}_{1}$, which in turn modulates AMPAR function and synaptic plasticity (Toda and Huganir, 2015). PACAP shows neuroprotective activity in various experimental models (Reglodi et al., 2000). PACAP and $\mathrm{PAC}_{1}$ are also involved in the regulation of neurodevelopment (Vaudry et al., 1999). PAC 1 is expressed in a sex-specific manner during development (Shneider et al., 2010). DPN modestly activates transcription of Adcyap1r1 coding for $\mathrm{PAC}_{1}$.

\section{Bradykinin Receptor 2}

B2 bradykinin receptor is widely expressed in neurons of the rat brain including the hippocampal formation (Chen et al., 2000). Bradykinin, released after tissue injury, specifically activates the B2 receptor (Albert-Weissenberger et al., 2013). The receptor increases the excitability of the hippocampus and its susceptibility to seizure (Rodi et al., 2013). We showed downregulation of $B d k r b 2$.

\section{Control of Potassium Channels}

Voltage-gated potassium channels play an indispensable role in the transition from depolarized to resting state of neurons. For potassium channel coding genes refer to: www.genenames.org/genefamilies/KCN. DPN treatment modulates mRNA expression of genes coding for various voltage-gated potassium channel alfa subunits and a single beta subunit. Alfa subunits include delayed rectifier Kcna6 (Kv1.6) and Kcnc2 (Kv3.2), and A-type Kcnd3 (Kv4.3) family members. The single modulatory beta subunit is Kcne2. DPN strongly activates transcription of Kcne 2 which is in line with the presence of estrogen response elements in the promoter region of the gene (Kundu et al., 2008). DPN modestly regulates Ca-activated potassium channel (Kcnma1), inwardly rectifying channel (Kcnj3), and tetramerization domain-containing 1 (Kctd1). With the exception of Kcnk2 and Kctd4, the DPN-controlled potassium channel coding genes were upregulated. Increased expression of Kcne2 may result in modulation of neuronal excitability via KCNQ2-KCNQ3 channel function in the hippocampus (Tinel et al., 2000). 


\section{Effects on Growth/Troph Hormone Signaling Insulin-Like Growth Factor System}

IGF2 is abundantly expressed in the rat hippocampus compared to peripheral organs (Ye et al., 2015). IGF2 is a potent regulator of adult hippocampal neurogenesis (Bracko et al., 2012) and memory consolidation (Chen et al., 2011). We found that DPN robustly activated mRNA expression of $\operatorname{Ig} f 2$. DPN also enhanced mRNA expression of $I g f b p 2$ and $I g f 1 r$, which are involved in the transport and recognition of IGF2, respectively. IGF1R mediates the effects of serum IGF1 on modulation of synaptic plasticity and hippocampal neurogenesis (Llorens-Martin et al., 2009). Disruption of Igf1 heavily influences brain development and results in loss of hippocampal granule cells (Beck et al., 1995).

\section{Brain Derived Neurotrophic Factor}

Brain derived neurotrophic factor (BDNF) mRNA is localized in neurons of the pyramidal cell layer, the granular layer and the hilus of the dentate gyrus (Wetmore et al., 1990). BDNF signaling has a pivotal role in hippocampal neuroprotection, neurogenesis, and affects depression-associated behaviors (Taliaz et al., 2010). BDNF mRNA expression in the hippocampus fluctuates across the estrous cycle and increases in response to E2 (Gibbs, 1998). DPN moderately decreases mRNA expression of $B d n f$.

\section{Fibroblast Growth Factor}

Fgf1 encodes acidic fibroblast growth factor which is synthesized by the brain vasculature and can induce proliferation of progenitor cells. FGF1 mRNA is also found in the pyramidal cell layer and dentate granule cells of the rat hippocampus (Wilcox and Unnerstall, 1991), although the number of FGF1-IR neurons is rather low in the hippocampus (Stock et al., 1992). We found that DPN moderately activates transcription of Fgfl.

\section{Midkine}

Midkine is a heparin-binding growth factor which is widely expressed in the developing nervous system. It is expressed in NSPCs and enhances their growth and survival (Zou et al., 2006). The expression of midkine is limited to a few cell types in the adult brain (Bloch et al., 1992). DPN moderately upregulates Mdk expression.

\section{Increase of Klotho Signaling}

Klotho is a pleiotropic gene the overexpression of which extends lifespan in mice (Kurosu et al., 2005). Klotho is highly expressed in the choroid plexus and in neurons of the hippocampus (Kuro-o et al., 1997). It encodes a type I membrane protein which can be cleaved by metalloproteases and released from the cell membrane. Klotho promotes FGF-23 signaling, inhibits insulin/IGF1 signaling and regulates $\mathrm{Ca}^{++}$homeostasis (Imura et al., 2007). In mice, systemic overexpression of klotho improves learning and memory, and elevates synaptic NR2B in a subunitspecific manner through posttranscriptional mechanism (Dubal et al., 2014). We demonstrated that DPN robustly activates mRNA expression of klotho.

\section{Regulation of Transcription}

The homeobox-containing transcription factor Otx2 plays an indispensable role in normal brain development, but its role is enigmatic in adulthood. The passage of Otx 2 between cells by non-conventional mechanism gives another layer of complexity to the mechanism of action of Otx2 (Prochiantz and Theodore, 1995). Accumulation of Otx2 is required for the maturation of PV-containing interneurons (Sugiyama et al., 2008). Long-term DPN treatment highly activates mRNA expression of Otx2 which may influence hippocampal plasticity. DPN also increases mRNA expression of serum response factor (Srf), myelin transcription factor 1 (Myt1), muscle segment homeobox (Msx1), pre-B cell leukemia homeobox (Pbx1), transcription factor 12 (Tcf12), and mediator 1 (Med1). Srf controls activity-dependent immediateearly gene expression and synaptic strength in CA1 pyramidal neurons (Ramanan et al., 2005). Mice with deletion of Srf in the forebrain show impaired LTD and selective deficit in explicit spatial memory (Etkin et al., 2006). These findings suggest a crucial role for Srf in learning. Myt1 is expressed in neural progenitors and oligodendrocytes, and is likely to regulate oligodendrocyte differentiation (Armstrong et al., 1995). In the hippocampus, Msx1 is localized to astrocytes, oligodendrocytes, and immature oligodendrocytes (Ramos et al., 2004). Pbx1 is highly expressed in the developing rat brain and its expression is maintained in TuJ1-IR postmitotic neurons (Redmond et al., 1996). We showed that DPN decreases mRNA expression of Fos, which is in line with the presence of an estrogen response element-like sequence in its promoter region (Cattaneo and Maggi, 1990).

Cyclin-dependent kinases (Cdk) form complexes with cyclins and operate as transcription factors. Depletion of Cdk10 impairs progenitor cell survival (Yeh et al., 2013), therefore DPNevoked upregulation of $C d k 10$ may improve neural stem and progenitor cell (NSPC) survival. Deletion of $C d k n 1 c$ initially causes increased neurogenesis, while on the long run leads to impaired neurogenesis in the hippocampus (Furutachi et al., 2013). We found that DPN enhances Cdkn1c mRNA expression. DPN inversely modulates the transcription of coregulators, activates Ncorl and suppresses Crebbp and Ncoa6, among others. DPN also activates the transcription of Polr $2 b$ encoding DNA-directed RNA polymerase II polypeptide B. DPN can affect mRNA splicing and metabolism by upregulating splicing factors (Sfrs11, Srrm1), spliceosome components (Snrpg) and ribonucleoproteins (Hnrnpd, Hnrnpf, Prpf3). These findings suggest that DPN widely alters the transcriptional machinery in the hippocampus.

\section{Functional Considerations Neuronal Plasticity}

In females, structure and function of the tri-synaptic circuit of the hippocampal formation is responsive to changes of gonadal hormone levels. The neuronal response to E2, which takes place within $15 \mathrm{~min}$, includes dendritic remodeling and synaptic turnover. The role of fast, nongenomic effects has been explored and recognized, while the role of genomic effects has remained unexplored. This study demonstrates that selective activation of $\operatorname{ER} \beta$ leads to robust alteration of mRNA 
expression of growth/troph factor genes and modest changes of neurotransmitter and peptide receptor genes.

In the hippocampus, AMPA-type glutamate receptors (AMPAR) are composed of GluR1/2 and GluR2/3 heterodimers. As AMPAR mediates the majority of fast synaptic transmission, the modulation of its composition and phosphorylation control synaptic strength and cell firing (Huganir and Nicoll, 2013). Upregulation of genes coding for AMPA receptor subunits GluR2 (Gria2) and GluR3 (Gria3) may increase constitutive insertion of GluR2/3 heterodimers shifting the composition of synaptic AMPA receptors. The DPN-evoked increase of GluR2 content may reduce $\mathrm{Ca}^{++}$influx and decrease the potential of excitatory events (Hume et al., 1991). The level and site of GluR1 phosphorylation are regulated by various receptors including $\beta$-adrenergic receptor, $\mathrm{ml}$ acetylcholine receptor (Seol et al., 2007) and $\mathrm{PAC}_{1}$ (Toda and Huganir, 2015), among others. Alterations in the expression of these receptors may affect phosphorylation state of GluR1. In addition, downregulation of vesicular glutamate transporter 1 (Slc17a7) suggests a decreased synaptic glutamate pool in pyramidal and dentate granule cells. We also showed significant suppression of vesicular GABA transporter (Slc32a1) expression which indicates a decreased inhibitory tone in the hippocampus after chronic DPN treatment. Decreased Cck expression implicates CCK interneurons in the alterations related to inhibitory neurotransmission.

\section{Neurogenesis}

Neuronal plasticity also includes replacement of nonfunctional cells by the proliferation, differentiation and migration of NSPCs in the adult hippocampus. Proliferating (Ki-67+) and migrating $(\mathrm{DC}+)$ cells of the dentate gyrus express $\mathrm{ER} \beta$ and $\mathrm{ER} \alpha$ mRNA (Isgor and Watson, 2005). Extranuclear $\operatorname{ER} \beta$ is localized to DC-containing cells in the dentate gyrus of adult rats (Herrick et al., 2006). Various laboratories have demonstrated that selective ER $\beta$ agonists promote neurogenesis in the dentate gyrus (Mazzucco et al., 2006; Clark et al., 2012). Our study identified robust, ER $\beta$-dependent transcriptional regulation of key genes that are involved in NSPC proliferation and survival. Important upregulated genes associated with neurogenesis were Igf2 (along with Igfbp2, Igf1r), Fgf1, Mdk, Prlr, Cdk10, and $C d k n 1 c$. Insulin-like growth factor 2 is the master regulator of adult neurogenesis in the subgranular zone (Bracko et al., 2012; Ouchi et al., 2013). In accord, Igf2 is expressed in progenitor cells and can regulate cell proliferation and differentiation in autocrine manner (Ferron et al., 2015). Acidic fibroblast growth factor maintains proliferation, self-renewal and survival of NSPC via binding to FGF receptors (Ray and Gage, 2006; Ma et al., 2009). Midkine enhances the growth and survival of NSPC (Zou et al., 2006). Prolactin can induce adult neurogenesis in the hippocampus (Shingo et al., 2003; Larsen and Grattan, 2012). Regulation of cyclin-dependent kinase activity affects proliferation and survival of progenitor cells (Furutachi et al., 2013; Yeh et al., 2013). Of note, downregulation of $B d n f$ may also have a strong impact on neurogenesis (Maisonpierre et al., 1990). These results demonstrate that the ER $\beta$ agonist DPN modulates the transcription of several major regulators of NSPC proliferation, differentiation, and survival.

\section{Neuroprotection}

Both $\operatorname{ER} \alpha$ and $\operatorname{ER} \beta$ selective agonists exert neuroprotective effects (Zhao et al., 2004). It is likely that multiple mechanisms are responsible for the neuroprotective action of $\operatorname{ER} \beta$ agonists, and one of the putative mechanisms is myelination. In a mouse experimental autoimmune encephalomyelitis model, DPN promotes myelination and protects neurons (Khalaj et al., 2013). Cellular targets of the ER $\beta$ agonist in this case are cells of the oligodendrocyte lineage. DPN can enhance oligodendrocyte maturation via klotho signaling (Chen et al., 2013) and via transcription factors such as Msx1 and Myt1 (Armstrong et al., 1995). Upregulation of $M b p$ supports this notion.

DPN robustly activates transcription of klotho. Klotho expression is detectable in the rat brain including the hippocampus (Clinton et al., 2013). It protects neurons against neurodegeneration and oxidative stress via regulation of members of the redox system (Zeldich et al., 2014). In a mouse model, inverse correlation was shown between klotho expression and Alzheimer's disease phenotype (Kuang et al., 2014). Neurohormones, such as prolactin and PACAP protect hippocampal neurons following excitotoxic insult (Morales et al., 2014) and ischemia (Ohtaki et al., 2006), respectively. Upregulation of their receptors may potentiate the protective effects of these neurohormones in the hippocampus.

Another protective mechanism is mediated by transient receptor potential melastatin 7 (Trpm7) which is downregulated by DPN. Trpm7 in hippocampal neurons detects extracellular divalent cations (Wei et al., 2007). Inhibition of Trpm7 expression blocks Trpm7 currents, anoxic $\mathrm{Ca}^{++}$-uptake, ROS production and anoxic death (Aarts et al., 2003). Suppression of Trpm7 makes neurons resistant to ischemic death following brain ischemia (Sun et al., 2009). These data suggest that downregulation of Trpm 7 provides protection against ischemia after long-term DPN treatment.

It has been demonstrated that some E2 binding sites were associated with mitochondria in dendritic shafts and spines of the rat hippocampus (Milner et al., 2008). In accord, E2 modulates the brain mitochondrial proteome (Nilsen et al., 2007) and regulates oxidative metabolism in mitochondria (Irwin et al., 2008). DPN significantly increases the association of ER $\beta$ with mitochondria and enhances protein expression of ATP synthase in the hippocampus (Irwin et al., 2012). We found that DPN modestly enhances mRNA expression of ATP synthase (Atp5l, Atp5e), cytochrome c oxidase VIII (Cox8b) and some mitochondrial ribosomal protein genes (Mrpl42, Mrps16, Mrps27) which may reflect elevated mitochondrial ATP synthesis supporting hippocampal functions.

Glutathione peroxidase is the major enzyme to remove the excess of cytosolic and mitochondrial hydrogen peroxide in neurons (Desagher et al., 1996). Moderate upregulation of Gpx1 may provide enhanced protection against hydroxyl radical formation in the hippocampus.

Modulation of innate immune processes in the brain may also affect neuroprotection. We have recently published that DPN 


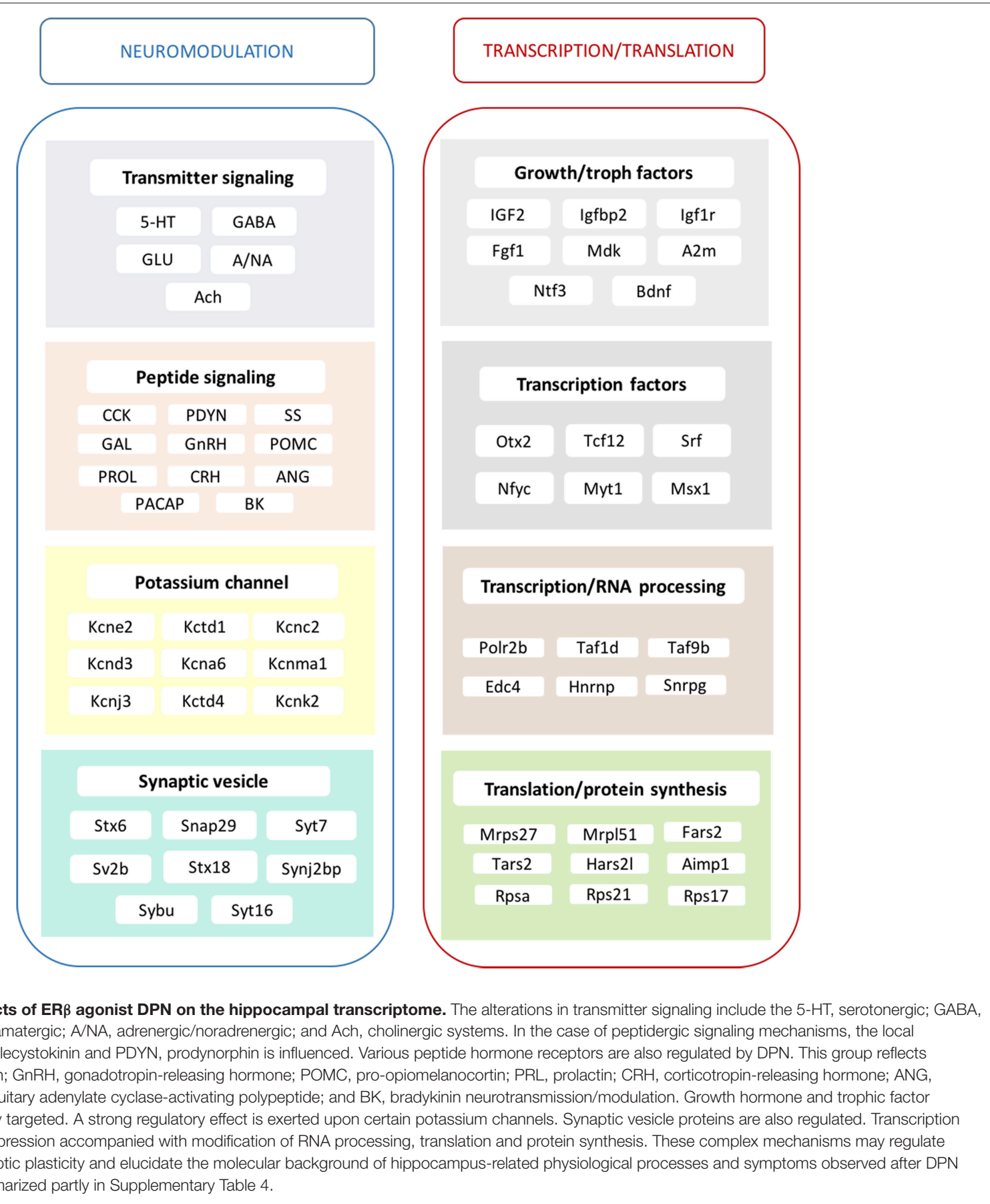

attenuates mRNA expression of some macrophage-associated and complement genes in the hippocampus (Sarvari et al., 2014). Here we showed upregulation of additional immune genes such as Cd59, Irak1, Cxcr4, and Mif. Upregulation of Cd59 and Irak1 may enhance the protection against homologous complement lysis (Singhrao et al., 2000) and promote the initial response to TLR stimulation (Kawagoe et al., 2008), respectively.

Concerning limitations, first we note that pharmacological approaches in $\operatorname{ER} \beta$ research are hindered by the moderate selectivity of $\operatorname{ER} \beta$ agonists. In a chronic paradigm it seems reasonable to assume that nonselective actions on $\mathrm{ER} \alpha$ may occur. However, the lack of the hallmark of $\mathrm{ER} \alpha$, namely its proliferating effect in the uterus, does not support this notion. In the hippocampus, DPN in part exerts overlapping transcriptional effects with E2, but there are clear differences (Sarvari et al., 2015). In addition, DPN distinctly regulates mRNA expression of some immune genes ( $M r c 1, C d 163, C d 200 r 1, C f b, C f p)$ in the hippocampus (Sarvari et al., 2014). These data support the view 
that at the applied dose DPN selectively activates ER $\beta$. Second, during the course of treatment DPN modulates the expression of growth factors, transcriptional regulators and transcription factors, among others. Therefore, primary and secondary effects on gene transcription can be hardly identified at the end of treatment. Third, one of the most responsive genes is Ttr. It is in accord with the presence of a putative estrogen-response element within the $5^{\prime}$ flanking region of TTR (Martinho et al., 2013). Transthyretin is mainly synthesized in the brain by the choroid plexus, and its expression is regulated by E2 (Tang et al., 2004). Although mRNA expression of Ttr in the hippocampus (Wang et al., 2014) and increased level of the protein in the dentate gyrus during memory consolidation (Monopoli et al., 2011) support local synthesis, contribution of the choroid plexus can't be ruled out since we can't exclude the presence of traces of choroid plexus in the dissected hippocampus. Fourth, the transcriptional effects of ER ligands partly depend on the chemical structure of the compound (Kuiper et al., 1998). Therefore, it is likely that various agonists exert slightly different transcriptional effects, i.e., some genes may show DPN specific regulation.

Summing up, long-term $\operatorname{ER} \beta$ agonist treatment evokes a broad array of changes in the hippocampal transcriptome of middle-aged, ovariectomized rats (Figure 4). A significant set of DPN-regulated genes was reminiscent to those seen in response to E2 (Sarvari et al., 2015). The identified basic cellular and

\section{REFERENCES}

Aarts, M., Iihara, K., Wei, W. L., Xiong, Z. G., Arundine, M., Cerwinski, W., et al. (2003). A key role for TRPM7 channels in anoxic neuronal death. Cell 115, 863-877. doi: 10.1016/S0092-8674(03)01017-1

Albert-Weissenberger, C., Siren, A. L., and Kleinschnitz, C. (2013). Ischemic stroke and traumatic brain injury: the role of the kallikrein-kinin system. Prog. Neurobiol. 101-102, 65-82. doi: 10.1016/j.pneurobio.2012.11.004

Altschuler, R. A., Monaghan, D. T., Haser, W. G., Wenthold, R. J., Curthoys, N. P., and Cotman, C. W. (1985). Immunocytochemical localization of glutaminase-like and aspartate aminotransferase-like immunoreactivities in the rat and guinea pig hippocampus. Brain Res. 330, 225-233. doi: 10.1016/00068993(85)90681-X

Armstrong, R. C., Kim, J. G., and Hudson, L. D. (1995). Expression of myelin transcription factor I (MyTI), a "zinc-finger" DNA-binding protein, in developing oligodendrocytes. Glia 14, 303-321. doi: 10.1002/glia.4401 40407

Badr, M., and Pelletier, G. (1987). Characterization and autoradiographic localization of LHRH receptors in the rat brain. Synapse 1, 567-571. doi: 10.1002/syn.890010609

Bakowska, J. C., and Morrell, J. I. (1997). Atlas of the neurons that express mRNA for the long form of the prolactin receptor in the forebrain of the female rat. J. Comp. Neurol. 386, 161-177.

Beck, K. D., Powell-Braxton, L., Widmer, H. R., Valverde, J., and Hefti, F. (1995). Igf1 gene disruption results in reduced brain size, CNS hypomyelination, and loss of hippocampal granule and striatal parvalbumin-containing neurons. Neuron 14, 717-730. doi: 10.1016/0896-6273(95)90216-3

Bloch, B., Normand, E., Kovesdi, I., and Bohlen, P. (1992). Expression of the HBNF (heparin-binding neurite-promoting factor) gene in the brain of fetal, neonatal and adult rat: an in situ hybridization study. Brain Res. Dev. Brain Res. 70, 267-278. doi: 10.1016/0165-3806(92)90206-C

Bracko, O., Singer, T., Aigner, S., Knobloch, M., Winner, B., Ray, J., et al. (2012). Gene expression profiling of neural stem cells and their neuronal progeny reveals IGF2 as a regulator of adult hippocampal neurogenesis. J. Neurosci. 32, 3376-3387. doi: 10.1523/JNEUROSCI.4248-11.2012 neuronal network mechanisms are utilized in the regulation of neuronal plasticity, neurogenesis, and neuroprotection in the hippocampal formation. These events are known to influence learning, memory, spatial navigation and mood/behavior-related events (Supplementary Table 4). Based on these results, we propose that $\operatorname{ER} \beta$ agonist treatment may represent a safe and effective estrogen replacement therapy to preserve the integrity of the hippocampal formation in the postmenopausal period.

\section{AUTHOR CONTRIBUTIONS}

ZL, MS conceived and designed experiments. MS, IK, EH, AR performed experiments. MS, NS, ZL analyzed data. MS, ZL wrote the paper.

\section{FUNDING}

This work was supported by the Hungarian Scientific Research Fund Grant OTKA K100722 for ZL.

\section{SUPPLEMENTARY MATERIAL}

The Supplementary Material for this article can be found online at: http://journal.frontiersin.org/article/10.3389/fncel. 2016.00149
Brailoiu, E., Dun, S. L., Brailoiu, G. C., Mizuo, K., Sklar, L. A., Oprea, T. I., et al. (2007). Distribution and characterization of estrogen receptor G proteincoupled receptor 30 in the rat central nervous system. J. Endocrinol. 193, 311-321. doi: 10.1677/JOE-07-0017

Cammalleri, M., Martini, D., Timperio, A. M., and Bagnoli, P. (2009). Functional effects of somatostatin receptor 1 activation on synaptic transmission in the mouse hippocampus. J. Neurochem. 111, 1466-1477. doi: 10.1111/j.14714159.2009.06423.x

Cardona, C., Sanchez-Mejias, E., Davila, J. C., Martin-Rufian, M., CamposSandoval, J. A., Vitorica, J., et al. (2015). Expression of Gls and Gls2 glutaminase isoforms in astrocytes. Glia 63, 365-382. doi: 10.1002/glia. 22758

Cardoso, C. C., Ricardo, V. P., Frussa-Filho, R., Porto, C. S., and Abdalla, F. M. (2010). Effects of 17ss-estradiol on expression of muscarinic acetylcholine receptor subtypes and estrogen receptor alpha in rat hippocampus. Eur. J. Pharmacol. 634, 192-200. doi: 10.1016/j.ejphar.2010. 02.032

Cattaneo, E., and Maggi, A. (1990). c-fos induction by estrogen in specific rat brain areas. Eur. J. Pharmacol. 188, 153-159. doi: 10.1016/0922-4106(90)90050-8

Chang, Y. J., Yang, C. H., Liang, Y. C., Yeh, C. M., Huang, C. C., and Hsu, K. S. (2009). Estrogen modulates sexually dimorphic contextual fear extinction in rats through estrogen receptor beta. Hippocampus 19, 1142-1150. doi: 10.1002/hipo.20581

Chaudhry, F. A., Reimer, R. J., Bellocchio, E. E., Danbolt, N. C., Osen, K. K., Edwards, R. H., et al. (1998). The vesicular GABA transporter, VGAT, localizes to synaptic vesicles in sets of glycinergic as well as GABAergic neurons. J. Neurosci. 18, 9733-9750.

Chen, C. D., Sloane, J. A., Li, H., Aytan, N., Giannaris, E. L., Zeldich, E., et al. (2013). The antiaging protein Klotho enhances oligodendrocyte maturation and myelination of the CNS. J. Neurosci. 33, 1927-1939. doi: 10.1523/JNEUROSCI.2080-12.2013

Chen, D. Y., Stern, S. A., Garcia-Osta, A., Saunier-Rebori, B., Pollonini, G., Bambah-Mukku, D., et al. (2011). A critical role for IGF-II in memory consolidation and enhancement. Nature 469, 491-497. doi: 10.1038 /nature09667 
Chen, E. Y., Emerich, D. F., Bartus, R. T., and Kordower, J. H. (2000). B2 bradykinin receptor immunoreactivity in rat brain. J. Comp. Neurol. 427, 1-18. doi: 10.1002/1096-9861(20001106)427:1<1::AID-CNE1>3.0.CO;2-0

Clark, J. A., Alves, S., Gundlah, C., Rocha, B., Birzin, E. T., Cai, S. J., et al. (2012). Selective estrogen receptor-beta (SERM-beta) compounds modulate raphe nuclei tryptophan hydroxylase-1 (TPH-1) mRNA expression and cause antidepressant-like effects in the forced swim test. Neuropharmacology 63, 1051-1063. doi: 10.1016/j.neuropharm.2012.07.004

Clinton, S. M., Glover, M. E., Maltare, A., Laszczyk, A. M., Mehi, S. J., Simmons, R. K., et al. (2013). Expression of klotho mRNA and protein in rat brain parenchyma from early postnatal development into adulthood. Brain Res. 1527, 1-14. doi: 10.1016/j.brainres.2013.06.044

Cox, D. J., Racca, C., and LeBeau, F. E. (2008). Beta-adrenergic receptors are differentially expressed in distinct interneuron subtypes in the rat hippocampus. J. Comp. Neurol. 509, 551-565. doi: 10.1002/cne. 21758

Day, M., Sung, A., Logue, S., Bowlby, M., and Arias, R. (2005). Beta estrogen receptor knockout (BERKO) mice present attenuated hippocampal CA1 longterm potentiation and related memory deficits in contextual fear conditioning. Behav. Brain Res. 164, 128-131. doi: 10.1016/j.bbr.2005.05.011

Depczynski, B., Nichol, K., Fathi, Z., Iismaa, T., Shine, J., and Cunningham, A. (1998). Distribution and characterization of the cell types expressing GALR2 mRNA in brain and pituitary gland. Ann. N.Y. Acad. Sci. 863, 120-128. doi: 10.1111/j.1749-6632.1998.tb10689.x

Desagher, S., Glowinski, J., and Premont, J. (1996). Astrocytes protect neurons from hydrogen peroxide toxicity. J. Neurosci. 16, 2553-2562.

Dubal, D. B., Yokoyama, J. S., Zhu, L., Broestl, L., Worden, K., Wang, D., et al. (2014). Life extension factor klotho enhances cognition. Cell Rep. 7, 1065-1076. doi: 10.1016/j.celrep.2014.03.076

Emanuele, N. V., Jurgens, J. K., Halloran, M. M., Tentler, J. J., Lawrence, A. M., and Kelley, M. R. (1992). The rat prolactin gene is expressed in brain tissue: detection of normal and alternatively spliced prolactin messenger RNA. Mol. Endocrinol. 6, 35-42.

Etkin, A., Alarcon, J. M., Weisberg, S. P., Touzani, K., Huang, Y. Y., Nordheim, A., et al. (2006). A role in learning for SRF: deletion in the adult forebrain disrupts LTD and the formation of an immediate memory of a novel context. Neuron 50, 127-143. doi: 10.1016/j.neuron.2006.03.013

Ferron, S. R., Radford, E. J., Domingo-Muelas, A., Kleine, I., Ramme, A., Gray, D., et al. (2015). Differential genomic imprinting regulates paracrine and autocrine roles of IGF2 in mouse adult neurogenesis. Nat. Commun. 6, 8265. doi: $10.1038 /$ ncomms 9265

Foster, T. C., Rani, A., Kumar, A., Cui, L., and Semple-Rowland, S. L. (2008). Viral vector-mediated delivery of estrogen receptor-alpha to the hippocampus improves spatial learning in estrogen receptor-alpha knockout mice. Mol. Ther. 16, 1587-1593. doi: 10.1038/mt.2008.140

Fotuhi, M., Standaert, D. G., Testa, C. M., Penney, J. B. Jr., and Young, A. B. (1994). Differential expression of metabotropic glutamate receptors in the hippocampus and entorhinal cortex of the rat. Brain Res. Mol. Brain Res. 21, 283-292. doi: 10.1016/0169-328X(94)90259-3

Foy, M. R., Xu, J., Xie, X., Brinton, R. D., Thompson, R. F., and Berger, T. W. (1999). 17beta-estradiol enhances NMDA receptor-mediated EPSPs and long-term potentiation. J. Neurophysiol. 81, 925-929.

Fremeau, R. T. Jr., Voglmaier, S., Seal, R. P., and Edwards, R. H. (2004). VGLUTs define subsets of excitatory neurons and suggest novel roles for glutamate. Trends Neurosci. 27, 98-103. doi: 10.1016/j.tins.2003.11.005

Freund, T. F., and Buzsaki, G. (1996). Interneurons of the hippocampus. Hippocampus 6, 347-470.

Furutachi, S., Matsumoto, A., Nakayama, K. I., and Gotoh, Y. (2013). p57 controls adult neural stem cell quiescence and modulates the pace of lifelong neurogenesis. EMBO J. 32, 970-981. doi: 10.1038/emboj.2013.50

Gao, B., and Fritschy, J. M. (1994). Selective allocation of GABAA receptors containing the alpha 1 subunit to neurochemically distinct subpopulations of rat hippocampal interneurons. Eur. J. Neurosci. 6, 837-853. doi: 10.1111/j.14609568.1994.tb00994.x

Gibbs, R. B. (1998). Levels of trkA and BDNF mRNA, but not NGF mRNA, fluctuate across the estrous cycle and increase in response to acute hormone replacement. Brain Res. 787, 259-268. doi: 10.1016/S0006-8993(97)01511-4
Gould, E., Woolley, C. S., Frankfurt, M., and McEwen, B. S. (1990). Gonadal steroids regulate dendritic spine density in hippocampal pyramidal cells in adulthood. J. Neurosci. 10, 1286-1291.

Gronemeyer, H., Gustafsson, J. A., and Laudet, V. (2004). Principles for modulation of the nuclear receptor superfamily. Nat. Rev. Drug Discov. 3, 950-964. doi: 10.1038/nrd1551

Gustafson, E. L., Smith, K. E., Durkin, M. M., Gerald, C., and Branchek, T. A. (1996). Distribution of a rat galanin receptor mRNA in rat brain. Neuroreport 7, 953-957. doi: 10.1097/00001756-199603220-00025

Haas, H. L., Felix, D., Celio, M. R., and Inagami, T. (1980). Angiotensin II in the hippocampus. A histochemical and electrophysiological study. Experientia 36, 1394-1395. doi: 10.1007/BF01960117

Han, X., Aenlle, K. K., Bean, L. A., Rani, A., Semple-Rowland, S. L., Kumar, A., et al. (2013). Role of estrogen receptor alpha and beta in preserving hippocampal function during aging. J. Neurosci. 33, 2671-2683. doi: 10.1523/JNEUROSCI.4937-12.2013

Handel, M., Schulz, S., Stanarius, A., Schreff, M., Erdtmann-Vourliotis, M., Schmidt, H., et al. (1999). Selective targeting of somatostatin receptor 3 to neuronal cilia. Neuroscience 89, 909-926. doi: 10.1016/S0306-4522(98)00354-6

Handelmann, G., Meyer, D. K., Beinfeld, M. C., and Oertel, W. H. (1981). CCK-containing terminals in the hippocampus are derived from intrinsic neurons: an immunohistochemical and radioimmunological study. Brain Res. 224, 180-184. doi: 10.1016/0006-8993(81)91130-6

Herrick, S. P., Waters, E. M., Drake, C. T., McEwen, B. S., and Milner, T. A. (2006). Extranuclear estrogen receptor beta immunoreactivity is on doublecortincontaining cells in the adult and neonatal rat dentate gyrus. Brain Res. 1121, 46-58. doi: 10.1016/j.brainres.2006.08.084

Houser, C. R., and Esclapez, M. (1994). Localization of mRNAs encoding two forms of glutamic acid decarboxylase in the rat hippocampal formation. Hippocampus 4, 530-545. doi: 10.1002/hipo.450040503

Huang Da, W., Sherman, B. T., and Lempicki, R. A. (2009). Systematic and integrative analysis of large gene lists using DAVID bioinformatics resources. Nat. Protoc. 4, 44-57. doi: 10.1038/nprot.2008.211

Huganir, R. L., and Nicoll, R. A. (2013). AMPARs and synaptic plasticity: the last 25 years. Neuron 80, 704-717. doi: 10.1016/j.neuron.2013.10.025

Hughes, Z. A., Liu, F., Platt, B. J., Dwyer, J. M., Pulicicchio, C. M., Zhang, G., et al. (2008). WAY-200070, a selective agonist of estrogen receptor beta as a potential novel anxiolytic/antidepressant agent. Neuropharmacology 54, 1136-1142. doi: 10.1016/j.neuropharm.2008.03.004

Hume, R. I., Dingledine, R., and Heinemann, S. F. (1991). Identification of a site in glutamate receptor subunits that controls calcium permeability. Science 253, 1028-1031. doi: 10.1126/science. 1653450

Imura, A., Tsuji, Y., Murata, M., Maeda, R., Kubota, K., Iwano, A., et al. (2007). alpha-Klotho as a regulator of calcium homeostasis. Science 316, 1615-1618. doi: 10.1126/science.1135901

Innis, R. B., Correa, F. M., Uhl, G. R., Schneider, B., and Snyder, S. H. (1979). Cholecystokinin octapeptide-like immunoreactivity: histochemical localization in rat brain. Proc. Natl. Acad. Sci. U.S.A. 76, 521-525. doi: 10.1073/pnas.76.1.521

Irwin, R. W., Yao, J., Hamilton, R. T., Cadenas, E., Brinton, R. D., and Nilsen, J. (2008). Progesterone and estrogen regulate oxidative metabolism in brain mitochondria. Endocrinology 149, 3167-3175. doi: 10.1210/en.2007-1227

Irwin, R. W., Yao, J., To, J., Hamilton, R. T., Cadenas, E., and Brinton, R. D. (2012). Selective oestrogen receptor modulators differentially potentiate brain mitochondrial function. J. Neuroendocrinol. 24, 236-248. doi: 10.1111/j.13652826.2011.02251.x

Isgor, C., and Watson, S. J. (2005). Estrogen receptor alpha and beta mRNA expressions by proliferating and differentiating cells in the adult rat dentate gyrus and subventricular zone. Neuroscience 134, 847-856. doi: 10.1016/j.neuroscience.2005.05.008

Jacome, L. F., Gautreaux, C., Inagaki, T., Mohan, G., Alves, S., Lubbers, L. S. et al. (2010). Estradiol and ERbeta agonists enhance recognition memory, and DPN, an ERbeta agonist, alters brain monoamines. Neurobiol. Learn. Mem. 94, 488-498. doi: 10.1016/j.nlm.2010.08.016

Jennes, L., Brame, B., Centers, A., Janovick, J. A., and Conn, P. M. (1995). Regulation of hippocampal gonadotropin releasing hormone $(\mathrm{GnRH})$ receptor mRNA and GnRH-stimulated inositol phosphate production by gonadal 
steroid hormones. Brain Res. Mol. Brain Res. 33, 104-110. doi: 10.1016/0169328X(95)00113-7

Kawagoe, T., Sato, S., Matsushita, K., Kato, H., Matsui, K., Kumagai, Y., et al. (2008). Sequential control of Toll-like receptor-dependent responses by IRAK1 and IRAK2. Nat. Immunol. 9, 684-691. doi: 10.1038/ni.1606

Khalaj, A. J., Yoon, J., Nakai, J., Winchester, Z., Moore, S. M., Yoo, T., et al. (2013). Estrogen receptor (ER) beta expression in oligodendrocytes is required for attenuation of clinical disease by an ERbeta ligand. Proc. Natl. Acad. Sci. U.S.A. 110, 19125-19130. doi: 10.1073/pnas.1311763110

Kiss, A., Delattre, A. M., Pereira, S. I., Carolino, R. G., Szawka, R. E., AnselmoFranci, J. A., et al. (2012). 17beta-estradiol replacement in young, adult and middle-aged female ovariectomized rats promotes improvement of spatial reference memory and an antidepressant effect and alters monoamines and BDNF levels in memory- and depression-related brain areas. Behav. Brain Res. 227, 100-108. doi: 10.1016/j.bbr.2011.10.047

Kong, H., DePaoli, A. M., Breder, C. D., Yasuda, K., Bell, G. I., and Reisine, T. (1994). Differential expression of messenger RNAs for somatostatin receptor subtypes SSTR1, SSTR2 and SSTR3 in adult rat brain: analysis by RNA blotting and in situ hybridization histochemistry. Neuroscience 59, 175-184. doi: 10.1016/0306-4522(94)90108-2

Kosaka, T., Kosaka, K., Tateishi, K., Hamaoka, Y., Yanaihara, N., Wu, J. Y., et al. (1985). GABAergic neurons containing CCK-8-like and/or VIP-like immunoreactivities in the rat hippocampus and dentate gyrus. J. Comp. Neurol. 239, 420-430. doi: 10.1002/cne.902390408

Kuang, X., Chen, Y. S., Wang, L. F., Li, Y. J., Liu, K., Zhang, M. X., et al. (2014). Klotho upregulation contributes to the neuroprotection of ligustilide in an Alzheimer's disease mouse model. Neurobiol. Aging 35, 169-178. doi: 10.1016/j.neurobiolaging.2013.07.019

Kuiper, G. G., Enmark, E., Pelto-Huikko, M., Nilsson, S., and Gustafsson, J. A. (1996). Cloning of a novel receptor expressed in rat prostate and ovary. Proc. Natl. Acad. Sci. U.S.A. 93, 5925-5930. doi: 10.1073/pnas.93.12.5925

Kuiper, G. G., Lemmen, J. G., Carlsson, B., Corton, J. C., Safe, S. H., van der Saag, P. T., et al. (1998). Interaction of estrogenic chemicals and phytoestrogens with estrogen receptor beta. Endocrinology 139, 4252-4263.

Kundu, P., Ciobotaru, A., Foroughi, S., Toro, L., Stefani, E., and Eghbali, M. (2008). Hormonal regulation of cardiac KCNE2 gene expression. Mol. Cell. Endocrinol. 292, 50-62. doi: 10.1016/j.mce.2008.06.003

Kuro-o, M., Matsumura, Y., Aizawa, H., Kawaguchi, H., Suga, T., Utsugi, T., et al. (1997). Mutation of the mouse klotho gene leads to a syndrome resembling ageing. Nature 390, 45-51. doi: 10.1038/36285

Kurosu, H., Yamamoto, M., Clark, J. D., Pastor, J. V., Nandi, A., Gurnani, P., et al. (2005). Suppression of aging in mice by the hormone Klotho. Science 309, 1829-1833. doi: 10.1126/science.1112766

Larsen, C. M., and Grattan, D. R. (2012). Prolactin, neurogenesis, and maternal behaviors. Brain Behav. Immun. 26, 201-209. doi: 10.1016/j.bbi.2011.07.233

Li, X. H., Chen, J. X., Yue, G. X., Liu, Y. Y., Zhao, X., Guo, X. L., et al. (2013). Gene expression profile of the hippocampus of rats subjected to chronic immobilization stress. PLOS ONE 8:e57621. doi: 10.1371/journal.pone.0057621

Liu, F., Day, M., Muniz, L. C., Bitran, D., Arias, R., Revilla-Sanchez, R., et al. (2008). Activation of estrogen receptor-beta regulates hippocampal synaptic plasticity and improves memory. Nat. Neurosci. 11, 334-343. doi: 10.1038/nn2057

Llorens-Martin, M., Torres-Aleman, I., and Trejo, J. L. (2009). Mechanisms mediating brain plasticity: IGF1 and adult hippocampal neurogenesis. Neuroscientist 15, 134-148. doi: 10.1177/1073858408331371

Ma, D. K., Jang, M. H., Guo, J. U., Kitabatake, Y., Chang, M. L., Pow-Anpongkul, N., et al. (2009). Neuronal activity-induced Gadd45b promotes epigenetic DNA demethylation and adult neurogenesis. Science 323, 1074-1077. doi: 10.1126/science.1166859

Maisonpierre, P. C., Belluscio, L., Friedman, B., Alderson, R. F., Wiegand, S. J., Furth, M. E., et al. (1990). NT-3, BDNF, and NGF in the developing rat nervous system: parallel as well as reciprocal patterns of expression. Neuron 5, 501-509. doi: 10.1016/0896-6273(90)90089-X

Martinho, A., Santos, C. R., and Goncalves, I. (2013). A distal estrogen responsive element upstream the cap site of human transthyretin gene is an enhancer-like element upon ERalpha and/or ERbeta transactivation. Gene 527, 469-476. doi: 10.1016/j.gene.2013.06.078

Martini, L., Dondi, D., Limonta, P., Maggi, R., and Piva, F. (1989). Modulation by sex steroids of brain opioid receptors: implications for the control of gonadotropins and prolactin secretion. J. Steroid Biochem. 33, 673-681. doi: 10.1016/0022-4731(89)90477-9

Mazzucco, C. A., Lieblich, S. E., Bingham, B. I., Williamson, M. A., Viau, V., and Galea, L. A. (2006). Both estrogen receptor alpha and estrogen receptor beta agonists enhance cell proliferation in the dentate gyrus of adult female rats. Neuroscience 141, 1793-1800. doi: 10.1016/j.neuroscience.2006.05.032

McGinty, J. F., Henriksen, S. J., Goldstein, A., Terenius, L., and Bloom, F. E. (1983). Dynorphin is contained within hippocampal mossy fibers: immunochemical alterations after kainic acid administration and colchicineinduced neurotoxicity. Proc. Natl. Acad. Sci. U.S.A. 80, 589-593. doi: 10.1073/pnas.80.2.589

Melander, T., Staines, W. A., Hokfelt, T., Rokaeus, A., Eckenstein, F., Salvaterra, P. M., et al. (1985). Galanin-like immunoreactivity in cholinergic neurons of the septum-basal forebrain complex projecting to the hippocampus of the rat. Brain Res. 360, 130-138. doi: 10.1016/0006-8993(85)91228-4

Milner, T. A., Lubbers, L. S., Alves, S. E., and McEwen, B. S. (2008). Nuclear and extranuclear estrogen binding sites in the rat forebrain and autonomic medullary areas. Endocrinology 149, 3306-3312. doi: 10.1210/en.2008-0307

Mitterling, K. L., Spencer, J. L., Dziedzic, N., Shenoy, S., McCarthy, K., Waters, E. M., et al. (2010). Cellular and subcellular localization of estrogen and progestin receptor immunoreactivities in the mouse hippocampus. J. Comp. Neurol. 518, 2729-2743. doi: 10.1002/cne.22361

Monopoli, M. P., Raghnaill, M. N., Loscher, J. S., O’Sullivan, N. C., Pangalos, M. N., Ring, R. H., et al. (2011). Temporal proteomic profile of memory consolidation in the rat hippocampal dentate gyrus. Proteomics 11, 4189-4201. doi: 10.1002/pmic.201100072

Morales, T., Lorenson, M., Walker, A. M., and Ramos, E. (2014). Both prolactin (PRL) and a molecular mimic of phosphorylated PRL, S179D-PRL, protect the hippocampus of female rats against excitotoxicity. Neuroscience 258, 211-217. doi: 10.1016/j.neuroscience.2013.11.015

Mukherjee, J., Kretschmannova, K., Gouzer, G., Maric, H. M., Ramsden, S., Tretter, V., et al. (2011). The residence time of GABA(A)Rs at inhibitory synapses is determined by direct binding of the receptor alphal subunit to gephyrin. $J$. Neurosci. 31, 14677-14687. doi: 10.1523/JNEUROSCI.2001-11.2011

Murphy, D. D., Cole, N. B., Greenberger, V., and Segal, M. (1998). Estradiol increases dendritic spine density by reducing GABA neurotransmission in hippocampal neurons. J. Neurosci. 18, 2550-2559.

Nagano, M., and Kelly, P. A. (1994). Tissue distribution and regulation of rat prolactin receptor gene expression. Quantitative analysis by polymerase chain reaction. J. Biol. Chem. 269, 13337-13345.

Nakamura, N. H., Rosell, D. R., Akama, K. T., and McEwen, B. S. (2004). Estrogen and ovariectomy regulate mRNA and protein of glutamic acid decarboxylases and cation-chloride cotransporters in the adult rat hippocampus. Neuroendocrinology 80, 308-323. doi: 10.1159/0000 83657

Narvaez, M., Borroto-Escuela, D. O., Millon, C., Gago, B., Flores-Burgess, A., Santin, L., et al. (2015). Galanin receptor 2-neuropeptide Y Y1 receptor interactions in the dentate gyrus are related with antidepressant-like effects. Brain Struct. Funct. doi: 10.1007/s00429-015-1153-1. [Epub ahead of print].

Nilsen, J., Irwin, R. W., Gallaher, T. K., and Brinton, R. D. (2007). Estradiol in vivo regulation of brain mitochondrial proteome. J. Neurosci. 27, 14069-14077. doi: 10.1523/JNEUROSCI.4391-07.2007

Ohtaki, H., Nakamachi, T., Dohi, K., Aizawa, Y., Takaki, A., Hodoyama, K., et al. (2006). Pituitary adenylate cyclase-activating polypeptide (PACAP) decreases ischemic neuronal cell death in association with IL-6. Proc. Natl. Acad. Sci. U.S.A. 103, 7488-7493. doi: 10.1073/pnas.0600375103

Ouchi, Y., Banno, Y., Shimizu, Y., Ando, S., Hasegawa, H., Adachi, K., et al. (2013). Reduced adult hippocampal neurogenesis and working memory deficits in the Dgcr8-deficient mouse model of 22q11.2 deletion-associated schizophrenia can be rescued by IGF2. J. Neurosci. 33, 9408-9419. doi: 10.1523/JNEUROSCI.2700-12.2013

Paschalis, A., Churchill, L., Marina, N., Kasymov, V., Gourine, A., and Ackland, G. (2009). betal-Adrenoceptor distribution in the rat brain: an immunohistochemical study. Neurosci. Lett. 458, 84-88. doi: 10.1016/j.neulet.2009.04.023

Pi, X. J., and Grattan, D. R. (1998). Distribution of prolactin receptor immunoreactivity in the brain of estrogen-treated, ovariectomized rats. J. Comp. Neurol. 394, 462-474. 
Pisani, S. L., Neese, S. L., Doerge, D. R., Helferich, W. G., Schantz, S. L., and Korol, D. L. (2012). Acute genistein treatment mimics the effects of estradiol by enhancing place learning and impairing response learning in young adult female rats. Horm. Behav. 62, 491-499. doi: 10.1016/j.yhbeh.2012. 08.006

Pisani, S. L., Neese, S. L., Katzenellenbogen, J. A., Schantz, S. L., and Korol, D. L. (2016). Estrogen receptor-selective agonists modulate learning in female rats in a dose- and task-specific manner. Endocrinology 157, 292-303. doi: 10.1210/en.2015-1616

Pompeiano, M., Palacios, J. M., and Mengod, G. (1994). Distribution of the serotonin 5-HT2 receptor family mRNAs: comparison between 5-HT2A and 5-HT2C receptors. Brain Res. Mol. Brain Res. 23, 163-178. doi: 10.1016/0169328X(94)90223-2

Prange-Kiel, J., Jarry, H., Schoen, M., Kohlmann, P., Lohse, C., Zhou, L., et al. (2008). Gonadotropin-releasing hormone regulates spine density via its regulatory role in hippocampal estrogen synthesis. J. Cell Biol. 180, 417-426. doi: $10.1083 /$ jcb.200707043

Prochiantz, A., and Theodore, L. (1995). Nuclear/growth factors. Bioessays 17, 39-44. doi: 10.1002/bies.950170109

Ramanan, N., Shen, Y., Sarsfield, S., Lemberger, T., Schutz, G., Linden, D. J., et al. (2005). SRF mediates activity-induced gene expression and synaptic plasticity but not neuronal viability. Nat. Neurosci. 8, 759-767. doi: 10.1038/nn1462

Ramos, C., Martinez, A., Robert, B., and Soriano, E. (2004). Msx1 expression in the adult mouse brain: characterization of populations of beta-galactosidasepositive cells in the hippocampus and fimbria. Neuroscience 127, 893-900. doi: 10.1016/j.neuroscience.2004.06.010

Ray, J., and Gage, F. H. (2006). Differential properties of adult rat and mouse brain-derived neural stem/progenitor cells. Mol. Cell. Neurosci. 31, 560-573. doi: 10.1016/j.mcn.2005.11.010

Redmond, L., Hockfield, S., and Morabito, M. A. (1996). The divergent homeobox gene PBX1 is expressed in the postnatal subventricular zone and interneurons of the olfactory bulb. J. Neurosci. 16, 2972-2982.

Reglodi, D., Somogyvari-Vigh, A., Vigh, S., Kozicz, T., and Arimura, A. (2000). Delayed systemic administration of PACAP38 is neuroprotective in transient middle cerebral artery occlusion in the rat. Stroke 31, 1411-1417. doi: 10.1161/01.STR.31.6.1411

Rhodes, M. E., and Frye, C. A. (2006). ERbeta-selective SERMs produce mnemonic-enhancing effects in the inhibitory avoidance and water maze tasks. Neurobiol. Learn. Mem. 85, 183-191. doi: 10.1016/j.nlm.2005.10.003

Rodgers, S. P., Bohacek, J., and Daniel, J. M. (2010). Transient estradiol exposure during middle age in ovariectomized rats exerts lasting effects on cognitive function and the hippocampus. Endocrinology 151, 1194-1203. doi: 10.1210/en.2009-1245

Rodi, D., Buzzi, A., Barbieri, M., Zucchini, S., Verlengia, G., Binaschi, A., et al. (2013). Bradykinin B(2) receptors increase hippocampal excitability and susceptibility to seizures in mice. Neuroscience 248, 392-402. doi: 10.1016/j.neuroscience.2013.06.038

Sarvari, M., Hrabovszky, E., Kallo, I., Solymosi, N., Toth, K., Liko, I., et al. (2011). Estrogens regulate neuroinflammatory genes via estrogen receptors alpha and beta in the frontal cortex of middle-aged female rats. J. Neuroinflammation 8 , 82. doi: 10.1186/1742-2094-8-82

Sarvari, M., Kallo, I., Hrabovszky, E., Solymosi, N., and Liposits, Z. (2014). Ovariectomy and subsequent treatment with estrogen receptor agonists tune the innate immune system of the hippocampus in middle-aged female rats. PLoS ONE 9:e88540. doi: 10.1371/journal.pone. 0088540

Sarvari, M., Kallo, I., Hrabovszky, E., Solymosi, N., Rodolosse, A., Vastagh, C., et al. (2015). Hippocampal gene expression is highly responsive to estradiol replacement in middle-aged female rats. Endocrinology 156, 2632-2645. doi: 10.1210/en.2015-1109

Sarvari, M., Kallo, I., Hrabovszky, E., Solymosi, N., Toth, K., Liko, I., et al. (2010). Estradiol replacement alters expression of genes related to neurotransmission and immune surveillance in the frontal cortex of middle-aged, ovariectomized rats. Endocrinology 151, 3847-3862. doi: 10.1210/en.2010-0375

Savasta, M., Palacios, J. M., and Mengod, G. (1988). Regional localization of the mRNA coding for the neuropeptide cholecystokinin in the rat brain studied by in situ hybridization. Neurosci. Lett. 93, 132-138. doi: 10.1016/03043940(88)90070-5
Savoy-Moore, R. T., Schwartz, N. B., Duncan, J. A., and Marshall, J. C. (1980), Pituitary gonadotropin-releasing hormone receptors during the rat estrous cycle. Science 209, 942-944. doi: 10.1126/science.6250218

Senaris, R. M., Humphrey, P. P., and Emson, P. C. (1994). Distribution of somatostatin receptors 1,2 and 3 mRNA in rat brain and pituitary. Eur. J. Neurosci. 6, 1883-1896. doi: 10.1111/j.1460-9568.1994.tb00579.x

Seol, G. H., Ziburkus, J., Huang, S., Song, L., Kim, I. T., Takamiya, K., et al. (2007). Neuromodulators control the polarity of spike-timing-dependent synaptic plasticity. Neuron 55, 919-929. doi: 10.1016/j.neuron.2007.08.013

Shingo, T., Gregg, C., Enwere, E., Fujikawa, H., Hassam, R., Geary, C., et al. (2003). Pregnancy-stimulated neurogenesis in the adult female forebrain mediated by prolactin. Science 299, 117-120. doi: 10.1126/science.1076647

Shneider, Y., Shtrauss, Y., Yadid, G., and Pinhasov, A. (2010). Differential expression of PACAP receptors in postnatal rat brain. Neuropeptides 44, 509-514. doi: 10.1016/j.npep.2010.09.001

Shughrue, P. J., Lane, M. V., and Merchenthaler, I. (1997). Comparative distribution of estrogen receptor-alpha and -beta mRNA in the rat central nervous system. J. Comp. Neurol. 388, 507-525.

Shughrue, P. J., and Merchenthaler, I. (2000). Evidence for novel estrogen binding sites in the rat hippocampus. Neuroscience 99, 605-612. doi: 10.1016/S0306$4522(00) 00242-6$

Singhrao, S. K., Neal, J. W., Rushmere, N. K., Morgan, B. P., and Gasque, P. (2000). Spontaneous classical pathway activation and deficiency of membrane regulators render human neurons susceptible to complement lysis. Am. J. Pathol. 157, 905-918. doi: 10.1016/S0002-9440(10)64604-4

Sirett, N. E., Bray, J. J., and Hubbard, J. I. (1981). Localization of immunoreactive angiotensin II in the hippocampus and striatum of rat brain. Brain Res. 217, 405-411. doi: 10.1016/0006-8993(81)90019-6

Stock, A., Kuzis, K., Woodward, W. R., Nishi, R., and Eckenstein, F. P. (1992). Localization of acidic fibroblast growth factor in specific subcortical neuronal populations. J. Neurosci. 12, 4688-4700.

Stumm, R. K., Zhou, C., Schulz, S., and Hollt, V. (2004). Neuronal types expressing mu- and delta-opioid receptor mRNA in the rat hippocampal formation. J. Comp. Neurol. 469, 107-118. doi: 10.1002/cne.10997

Sugiyama, S., Di Nardo, A. A., Aizawa, S., Matsuo, I., Volovitch, M., Prochiantz, A., et al. (2008). Experience-dependent transfer of Otx2 homeoprotein into the visual cortex activates postnatal plasticity. Cell 134, 508-520. doi: 10.1016/j.cell.2008.05.054

Sun, H. S., Jackson, M. F., Martin, L. J., Jansen, K., Teves, L., Cui, H., et al. (2009). Suppression of hippocampal TRPM7 protein prevents delayed neuronal death in brain ischemia. Nat. Neurosci. 12, 1300-1307. doi: 10.1038/nn.2395

Sun, J., Baudry, J., Katzenellenbogen, J. A., and Katzenellenbogen, B. S. (2003). Molecular basis for the subtype discrimination of the estrogen receptorbeta-selective ligand, diarylpropionitrile. Mol. Endocrinol. 17, 247-258. doi: 10.1210/me.2002-0341

Suzuki, H., Barros, R. P., Sugiyama, N., Krishnan, V., Yaden, B. C., Kim, H. J., et al. (2013). Involvement of estrogen receptor beta in maintenance of serotonergic neurons of the dorsal raphe. Mol. Psychiatry 18, 674-680. doi: $10.1038 / \mathrm{mp} .2012 .62$

Svoboda, K. R., Adams, C. E., and Lupica, C. R. (1999). Opioid receptor subtype expression defines morphologically distinct classes of hippocampal interneurons. J. Neurosci. 19, 85-95.

Talboom, J. S., Williams, B. J., Baxley, E. R., West, S. G., and Bimonte-Nelson, H. A. (2008). Higher levels of estradiol replacement correlate with better spatial memory in surgically menopausal young and middle-aged rats. Neurobiol. Learn. Mem. 90, 155-163. doi: 10.1016/j.nlm.2008.04.002

Taliaz, D., Stall, N., Dar, D. E., and Zangen, A. (2010). Knockdown of brain-derived neurotrophic factor in specific brain sites precipitates behaviors associated with depression and reduces neurogenesis. Mol. Psychiatry 15, 80-92. doi: $10.1038 / \mathrm{mp} .2009 .67$

Tanapat, P., Hastings, N. B., Reeves, A. J., and Gould, E. (1999). Estrogen stimulates a transient increase in the number of new neurons in the dentate gyrus of the adult female rat. J. Neurosci. 19, 5792-5801.

Tang, Y. P., Haslam, S. Z., Conrad, S. E., and Sisk, C. L. (2004). Estrogen increases brain expression of the mRNA encoding transthyretin, an amyloid beta scavenger protein. J. Alzheimers Dis. 6, 413-420. discussion: 443-419.

Tinel, N., Diochot, S., Lauritzen, I., Barhanin, J., Lazdunski, M., and Borsotto, M. (2000). M-type KCNQ2-KCNQ3 potassium channels are modulated by 
the KCNE2 subunit. FEBS Lett. 480, 137-141. doi: 10.1016/S0014-5793(00) 01918-9

Toda, A. M., and Huganir, R. L. (2015). Regulation of AMPA receptor phosphorylation by the neuropeptide PACAP38. Proc. Natl. Acad. Sci. U.S.A. 112, 6712-6717. doi: 10.1073/pnas.1507229112

Torner, L., Karg, S., Blume, A., Kandasamy, M., Kuhn, H. G., Winkler, J., et al. (2009). Prolactin prevents chronic stress-induced decrease of adult hippocampal neurogenesis and promotes neuronal fate. J. Neurosci. 29, 1826-1833. doi: 10.1523/JNEUROSCI.3178-08.2009

Vaidya, V. A., Marek, G. J., Aghajanian, G. K., and Duman, R. S. (1997). 5-HT2A receptor-mediated regulation of brain-derived neurotrophic factor mRNA in the hippocampus and the neocortex. J. Neurosci. 17, 2785-2795.

Van Pett, K., Viau, V., Bittencourt, J. C., Chan, R. K., Li, H. Y., Arias, C., et al. (2000). Distribution of mRNAs encoding CRF receptors in brain and pituitary of rat and mouse. J. Comp. Neurol. 428, 191-212. doi: 10.1002/10969861(20001211)428:2<191::AID-CNE1>3.0.CO;2-U

Vaudry, D., Gonzalez, B. J., Basille, M., Fournier, A., and Vaudry, H. (1999). Neurotrophic activity of pituitary adenylate cyclase-activating polypeptide on rat cerebellar cortex during development. Proc. Natl. Acad. Sci. U.S.A. 96, 9415-9420. doi: 10.1073/pnas.96.16.9415

Vegeto, E., Belcredito, S., Etteri, S., Ghisletti, S., Brusadelli, A., Meda, C., et al. (2003). Estrogen receptor-alpha mediates the brain antiinflammatory activity of estradiol. Proc. Natl. Acad. Sci. U.S.A. 100, 9614-9619. doi: 10.1073/pnas.1531957100

Vilaro, M. T., Palacios, J. M., and Mengod, G. (1990). Localization of m5 muscarinic receptor mRNA in rat brain examined by in situ hybridization histochemistry. Neurosci. Lett. 114, 154-159. doi: 10.1016/0304-3940(90)90064-G

Vizi, E. S., and Kiss, J. P. (1998). Neurochemistry and pharmacology of the major hippocampal transmitter systems: synaptic and nonsynaptic interactions. Hippocampus 8, 566-607.

Walf, A. A., and Frye, C. A. (2005). ERbeta-selective estrogen receptor modulators produce antianxiety behavior when administered systemically to ovariectomized rats. Neuropsychopharmacology 30, 1598-1609. doi: 10.1038/sj.npp.1300713

Walf, A. A., Koonce, C. J., and Frye, C. A. (2008). Estradiol or diarylpropionitrile administration to wild type, but not estrogen receptor beta knockout, mice enhances performance in the object recognition and object placement tasks. Neurobiol. Learn. Mem. 89, 513-521. doi: 10.1016/j.nlm.2008.01.008

Walker, T. L., Vukovic, J., Koudijs, M. M., Blackmore, D. G., Mackay, E. W., Sykes, A. M., et al. (2012). Prolactin stimulates precursor cells in the adult mouse hippocampus. PLoS ONE 7:e44371. doi: 10.1371/journal.pone.0044371

Wang, X., Cattaneo, F., Ryno, L., Hulleman, J., Reixach, N., and Buxbaum, J. N. (2014). The systemic amyloid precursor transthyretin (TTR) behaves as a neuronal stress protein regulated by HSF1 in SH-SY5Y human neuroblastoma cells and APP23 Alzheimer's disease model mice. J. Neurosci. 34, 7253-7265. doi: 10.1523/JNEUROSCI.4936-13.2014

Waters, E. M., Mitterling, K., Spencer, J. L., Mazid, S., McEwen, B. S., and Milner, T. A. (2009). Estrogen receptor alpha and beta specific agonists regulate expression of synaptic proteins in rat hippocampus. Brain Res. 1290, 1-11. doi: 10.1016/j.brainres.2009.06.090

Waters, E. M., Thompson, L. I., Patel, P., Gonzales, A. D., Ye, H. Z., Filardo, E. J., et al. (2015). G-protein-coupled estrogen receptor 1 is anatomically positioned to modulate synaptic plasticity in the mouse hippocampus. J. Neurosci. 35, 2384-2397. doi: 10.1523/JNEUROSCI.1298-14.2015

Weber, M. T., Rubin, L. H., and Maki, P. M. (2013). Cognition in perimenopause: the effect of transition stage. Menopause 20, 511-517. doi: 10.1097/gme.0b013e31827655e5

Wei, J., Walton, E. A., Milici, A., and Buccafusco, J. J. (1994). m1-m5 muscarinic receptor distribution in rat CNS by RT-PCR and HPLC. J. Neurochem. 63, 815-821. doi: 10.1046/j.1471-4159.1994.63030815.x

Wei, W. L., Sun, H. S., Olah, M. E., Sun, X., Czerwinska, E., Czerwinski, W., et al. (2007). TRPM7 channels in hippocampal neurons detect levels of extracellular divalent cations. Proc. Natl. Acad. Sci. U.S.A. 104, 16323-16328. doi: 10.1073/pnas.0701149104

Weisskopf, M. G., Zalutsky, R. A., and Nicoll, R. A. (1993). The opioid peptide dynorphin mediates heterosynaptic depression of hippocampal mossy fibre synapses and modulates long-term potentiation. Nature 362, 423-427. doi: $10.1038 / 362423 \mathrm{a} 0$

Wetmore, C., Ernfors, P., Persson, H., and Olson, L. (1990). Localization of brain-derived neurotrophic factor mRNA to neurons in the brain by in situ hybridization. Exp. Neurol. 109, 141-152. doi: 10.1016/0014-4886(90)90068-4

Wilcox, B. J., and Unnerstall, J. R. (1991). Expression of acidic fibroblast growth factor mRNA in the developing and adult rat brain. Neuron 6, 397-409. doi: 10.1016/0896-6273(91)90248-X

Wisden, W., Laurie, D. J., Monyer, H., and Seeburg, P. H. (1992). The distribution of 13 GABAA receptor subunit mRNAs in the rat brain. I. Telencephalon, diencephalon, mesencephalon. J. Neurosci. 12, 1040-1062.

Wong, M., Eaton, M. J., and Moss, R. L. (1990). Electrophysiological actions of luteinizing hormone-releasing hormone: intracellular studies in the rat hippocampal slice preparation. Synapse 5, 65-70. doi: 10.1002/syn.890050106

Woolley, C. S., Gould, E., Frankfurt, M., and McEwen, B. S. (1990). Naturally occurring fluctuation in dendritic spine density on adult hippocampal pyramidal neurons. J. Neurosci. 10, 4035-4039.

Woolley, C. S., Weiland, N. G., McEwen, B. S., and Schwartzkroin, P. A. (1997) Estradiol increases the sensitivity of hippocampal CA1 pyramidal cells to NMDA receptor-mediated synaptic input: correlation with dendritic spine density. J. Neurosci. 17, 1848-1859.

Wright, D. E., Seroogy, K. B., Lundgren, K. H., Davis, B. M., and Jennes, L. (1995) Comparative localization of serotonin1A, 1C, and 2 receptor subtype mRNAs in rat brain. J. Comp. Neurol. 351, 357-373. doi: 10.1002/cne.903510304

Ye, X., Kohtz, A., Pollonini, G., Riccio, A., and Alberini, C. M. (2015). Insulin like growth factor 2 expression in the rat brain both in basal condition and following learning predominantly derives from the maternal allele. PLoS ONE 10:e0141078. doi: 10.1371/journal.pone.0141078

Yeh, C. W., Kao, S. H., Cheng, Y. C., and Hsu, L. S. (2013). Knockdown of cyclin-dependent kinase 10 (cdk10) gene impairs neural progenitor survival via modulation of rafla gene expression. J. Biol. Chem. 288, 27927-27939. doi: 10.1074/jbc.M112.420265

Zeidan, M. A., Igoe, S. A., Linnman, C., Vitalo, A., Levine, J. B., Klibanski, A., et al. (2011). Estradiol modulates medial prefrontal cortex and amygdala activity during fear extinction in women and female rats. Biol. Psychiatry 70, 920-927. doi: 10.1016/j.biopsych.2011.05.016

Zeldich, E., Chen, C. D., Colvin, T. A., Bove-Fenderson, E. A., Liang, J., Tucker Zhou, T. B., et al. (2014). The neuroprotective effect of Klotho is mediated via regulation of members of the redox system. J. Biol. Chem. 289, 24700-24715. doi: 10.1074/jbc.M114.567321

Zhao, L., Wu, T. W., and Brinton, R. D. (2004). Estrogen receptor subtypes alpha and beta contribute to neuroprotection and increased Bcl-2 expression in primary hippocampal neurons. Brain Res. 1010, 22-34. doi: 10.1016/j.brainres.2004.02.066

Zhou, C. J., Kikuyama, S., Arimura, A., and Shioda, S. (2000). Distribution of PACAP receptor and its splice variants in the rat brain by in situ RTPCR. Ann. N.Y. Acad. Sci. 921, 373-374. doi: 10.1111/j.1749-6632.2000.tb 06997.x

Zieglgansberger, W., French, E. D., Siggins, G. R., and Bloom, F. E. (1979). Opioid peptides may excite hippocampal pyramidal neurons by inhibiting adjacent inhibitory interneurons. Science 205, 415-417. doi: 10.1126/science.451610

Zou, P., Muramatsu, H., Miyata, T., and Muramatsu, T. (2006). Midkine, a heparin-binding growth factor, is expressed in neural precursor cells and promotes their growth. J. Neurochem. 99, 1470-1479. doi: 10.1111/j.14714159.2006.04138.x

Conflict of Interest Statement: The authors declare that the research was conducted in the absence of any commercial or financial relationships that could be construed as a potential conflict of interest.

Copyright (c) 2016 Sárvári, Kalló, Hrabovszky, Solymosi, Rodolosse and Liposits. This is an open-access article distributed under the terms of the Creative Commons Attribution License (CC BY). The use, distribution or reproduction in other forums is permitted, provided the original author(s) or licensor are credited and that the original publication in this journal is cited, in accordance with accepted academic practice. No use, distribution or reproduction is permitted which does not comply with these terms. 